\title{
Crosstalk of Magnesium and Serum Lipids in Dyslipidemia and Associated Disorders: A Systematic Review
}

\author{
Mihnea-Alexandru Găman ${ }^{1,2, * \mathbb{D}}$, Elena-Codruța Dobrică ${ }^{3,4}$, Matei-Alexandru Cozma ${ }^{5}$, Ninel-Iacobus Antonie ${ }^{6}$, \\ Ana Maria Alexandra Stănescu ${ }^{1}$ (D), Amelia Maria Găman 3,7,*(D) and Camelia Cristina Diaconu 1,6,*(D)
}

Citation: Găman, M.-A.; Dobrică, E.-C.; Cozma, M.-A.; Antonie, N.-I.; Stănescu, A.M.A.; Găman, A.M.; Diaconu, C.C. Crosstalk of Magnesium and Serum Lipids in Dyslipidemia and Associated Disorders: A Systematic Review. Nutrients 2021, 13, 1411. https:// doi.org/10.3390/nu13051411

Academic Editors: Sara Castiglioni, Giovanna Farruggia and Concettina Cappadone

Received: 18 March 2021

Accepted: 20 April 2021

Published: 22 April 2021

Publisher's Note: MDPI stays neutral with regard to jurisdictional claims in published maps and institutional affiliations.

Copyright: (c) 2021 by the authors. Licensee MDPI, Basel, Switzerland. This article is an open access article distributed under the terms and conditions of the Creative Commons Attribution (CC BY) license (https:// creativecommons.org/licenses/by/ $4.0 /)$.
1 Faculty of Medicine, "Carol Davila" University of Medicine and Pharmacy, 050474 Bucharest, Romania; alexandrazotta@yahoo.com

2 Department of Hematology, Center of Hematology and Bone Marrow Transplantation, Fundeni Clinical Institute, 022328 Bucharest, Romania

3 Department of Pathophysiology, University of Medicine and Pharmacy of Craiova, 200349 Craiova, Romania; codrutadobrica@yahoo.com

4 Department of Dermatology, “Elias” University Emergency Hospital, 011461 Bucharest, Romania

5 Department of Gastroenterology, Colentina Clinical Hospital, 20125 Bucharest, Romania; matei.cozma@gmail.com

6 Department of Internal Medicine, Clinical Emergency Hospital of Bucharest, 14461 Bucharest, Romania; antonieninel@yahoo.com

7 Clinic of Hematology, Filantropia City Hospital, 200143 Craiova, Romania

* Correspondence: mihneagaman@yahoo.com (M.-A.G.); gamanamelia@yahoo.com (A.M.G.); drcameliadiaconu@gmail.com (C.C.D.)

\begin{abstract}
Dyslipidemia is a significant threat to public health worldwide and the identification of its pathogenic mechanisms, as well as novel lipid-lowering agents, are warranted. Magnesium $(\mathrm{Mg})$ is a key element to human health and its deficiency has been linked to the development of lipid abnormalities and related disorders, such as the metabolic syndrome, type 2 diabetes mellitus, or cardiovascular disease. In this review, we explored the associations of $\mathrm{Mg}$ (dietary intake, $\mathrm{Mg}$ concentrations in the body) and the lipid profile, as well as the impact of $\mathrm{Mg}$ supplementation on serum lipids. A systematic search was computed in PubMed/MEDLINE and the Cochrane Library and 3649 potentially relevant papers were detected and screened ( $n=3364$ following the removal of duplicates). After the removal of irrelevant manuscripts based on the screening of their titles and abstracts $(\mathrm{n}=3037)$, we examined the full-texts of 327 original papers. Finally, after we applied the exclusion and inclusion criteria, a number of 124 original articles were included in this review. Overall, the data analyzed in this review point out an association of $\mathrm{Mg}$ concentrations in the body with serum lipids in dyslipidemia and related disorders. However, further research is warranted to clarify whether a higher intake of $\mathrm{Mg}$ from the diet or via supplements can influence the lipid profile and exert lipid-lowering actions.
\end{abstract}

Keywords: magnesium; magnesemia; hypomagnesemia; lipids; cholesterol; triglycerides; dyslipidemia; hyperlipidemia; diabetes; metabolic syndrome

\section{Introduction}

Dyslipidemia has emerged as a significant threat to public health worldwide, with recent statistics revealing that its prevalence reaches $42.7 \%$ in China and $56.8 \%$ in the United States of America (USA). In addition, Lu et al. (2018) have pointed out that an alarming rate of the population suffering from this disorder is not aware of its lipid profile (26.7\% in the USA versus $80.4 \%$ in China), leading to poor treatment and control rates of lipid abnormalities (13.2\% and $4.6 \%$ in China versus 54.1 and $35.7 \%$ in the USA) [1]. Thus, identifying novel strategies to combat dyslipidemia are warranted, particularly due to its involvement in the development of and crosstalk with metabolic syndrome (MetS), type 2 
diabetes mellitus (T2DM), cardiovascular disease, obesity, hypertension, chronic kidney disease (CKD), and others [1-3].

Magnesium (Mg) seems to play a key role in a myriad of disorders, e.g., MetS, T2DM, obesity, hypertension, and its deficiency has been regarded as highly prevalent, with Piuri et al. (2021) ranking it as the most common electrolyte imbalance in high-income countries [4-6]. Taking this information into consideration, we may hypothesize that there is a crosstalk between $\mathrm{Mg}$ and serum lipids which may impact on the pathogenesis of dyslipidemia and its associated comorbidities, as well as that $\mathrm{Mg}$ supplementation might provide health benefits in patients suffering from cardiometabolic disorders.

Therefore, the aim of this review is to explore the associations of $\mathrm{Mg}$ (dietary intake, $\mathrm{Mg}$ concentrations in the body) and the lipid profile, i.e., total cholesterol (TC), triglycerides (TG), high-density lipoprotein cholesterol (HDL-C), low-density lipoprotein cholesterol (LDL-C), other lipoproteins (Lp), or apolipoproteins (apo), as well as the impact of $\mathrm{Mg}$ supplementation on these variables based on data derived from high-quality evidence such as randomized clinical trials (RCTs).

\section{Materials and Methods}

The protocol employed in this systematic review was based on the Preferred Reporting Items for Systematic reviews and Meta-Analyses (PRISMA) checklist [7].

Four investigators (M.-A.G., E.-C.D., M.-A.C., and N.-I.A.) independently computed a literature search in PubMed/MEDLINE and Cochrane Library from the inception of these databases until 25 February 2021. The following keywords and combinations of words was employed: ("magnesium" OR "magnesemia*" OR "magnesaemia") AND ("Lp(a)" OR "Triglycerides" OR “Cholesterol" OR "Cholesterol" OR "Lipoproteins, HDL" OR "Cholesterol, HDL" OR “Cholesterol, LDL" OR “Lipoproteins, LDL" OR “Hyperlipidemias" OR "Dyslipidemias" OR "Hypercholesterolemia" OR "lipoprotein triglyceride" OR LDL OR HDL OR "Total cholesterol" OR TG OR Triglyceride OR Triacylglycerol OR TAG OR "lipid profile" OR "low density lipoprotein" OR "high density lipoprotein" OR "blood lipids" OR "lipids*" OR "triglycerid*" OR "trigly*" OR triacylglycerol OR cholesterol OR LDL-C OR HDL-C OR Hyperlipidemia OR Hyperlipidemic OR Dyslipidemia OR Dyslipidemic OR Hypercholesterolemia OR Hypercholesterolaemia OR Hypercholesterolemic OR hypercholesterolaemic) NOT (review OR mice OR rats OR rodents).

We decided for the following inclusion criteria: 1. Original articles/research letters evaluating the relationship between $\mathrm{Mg}$ and serum lipids in dyslipidemia and related disorders OR Original articles/research letters evaluating the effects of $\mathrm{Mg}$ intake/supplementation on serum lipids in dyslipidemia and related disorders in humans; 2. the subjects recruited in these original studies were adults (aged $\geq 18$ years); 3 . the papers were published in English, French, Italian, or Romanian (the languages spoken by the investigators); 4 . the papers provided sufficient data regarding the relationship of $\mathrm{Mg}$ and serum lipids or the effects of $\mathrm{Mg}$ supplementation on serum lipids in dyslipidemia and related disorders; 5 . the full-text of the papers could be downloaded/retrieved. We decided for the following exclusion criteria: 1 . Reviews, letters to the editor, case reports, conference abstracts, grey literature; 2 . the studies were conducted in vitro, on animals or in human subjects aged $<18$ years; 3 . the papers were published in languages unknown to the authors (e.g., Chinese, Polish etc.); 4 . the papers did not report sufficient data on the outcomes; 5 . the full-text of the articles was unavailable to the investigators.

Relevant data were extracted independently by four investigators (M.-A.G., E.-C.D., M.-A.C., and N.-I.A.) and disagreements were resolved by consultation with the senior authors (C.C.D. and A.M.G.).

\section{Results}

A total of 3649 potentially relevant papers were detected and screened. A flowchart diagram of the detailed steps of the literature search process is illustrated in Figure 1. After we removed the duplicates and excluded the irrelevant manuscripts based on the screening 
of their titles and abstracts $(n=3322)$, we examined the full-texts of 327 original papers. Finally, after we applied the exclusion and inclusion criteria, a number of 124 original articles were included in this review.

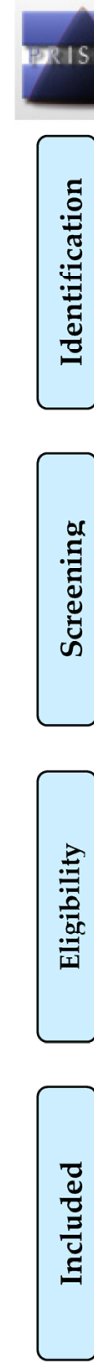

\section{PRISMA 2009 Flow Diagram}
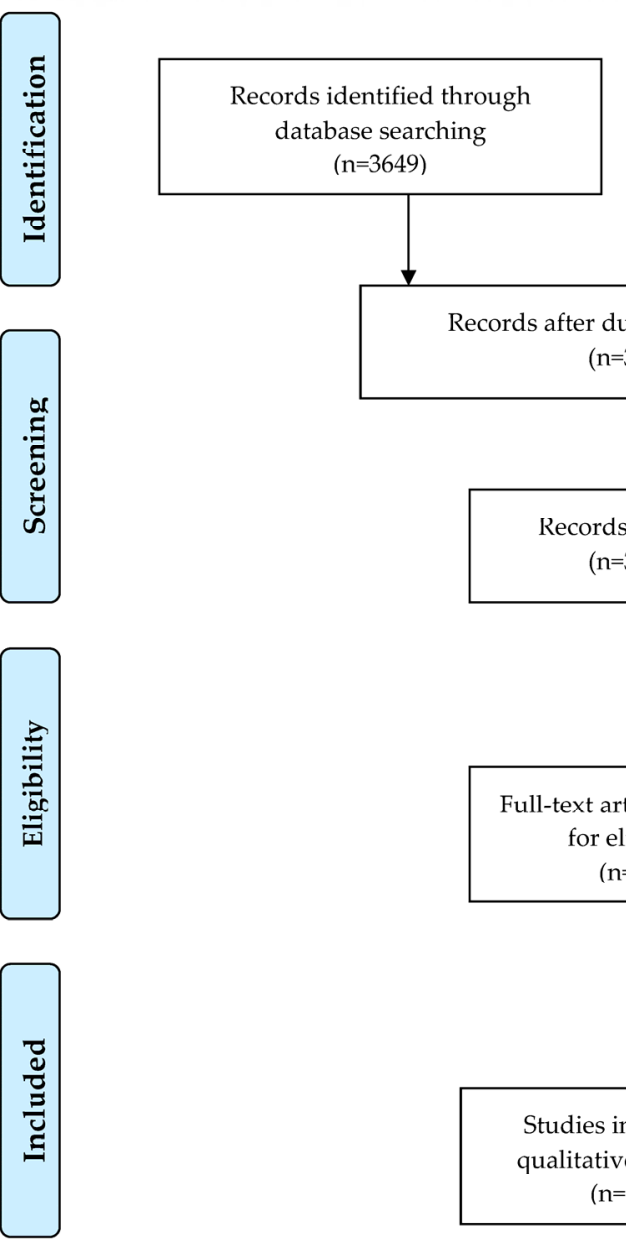

Additional records identified through other sources $(\mathrm{n}=0)$

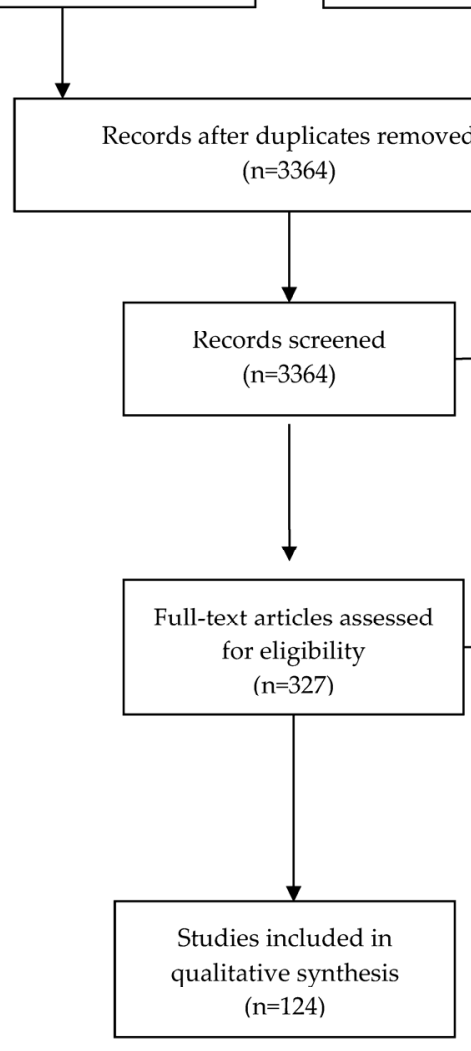

Figure 1. PRISMA 2009 Flow Diagram. From Moher, D.; Liberati, A.; Tetzlaff, J.; Altman, D.G. The Prisma Group. Preferred reporting items for systematic reviews and meta-analyses: The PRISMA statement. PLoS Med. 2009, 6, e1000097, doi:10.1371/journal.pmed.1000097. For more information, visit www.prisma-statement.org (accessed on 18 March 2021) [7].

\subsection{Crosstalk of Magnesium, Serum Lipids, and Dyslipidemia}

A total of 36 studies assessed the crosstalk of $\mathrm{Mg}$, serum lipids, and dyslipidemia, of which the vast majority was focused on the relationship of serum $\mathrm{Mg}$ with the lipid profile and lipid abnormalities, including the impact of dietary $\mathrm{Mg}$ intake or $\mathrm{Mg}$ supplementation on these parameters $(n=25)$. Several studies tackled the Mg-serum lipids crosstalk in overweight/obesity, polycystic ovary syndrome, or nonalcoholic fatty liver disease $(n=11)$. The most relevant information of this subsection are summarized in Table 1.

\subsubsection{Magnesium, Serum Lipids, and Dyslipidemia}

Barragán et al. (2020) evaluated the crosstalk between Mg concentrations, hypercholesterolemia, T2DM, and other cardiovascular risk factors in a Spanish cohort of 492 subjects. Hypomagnesemia was detected in nearly $19 \%$ of the study group, with no significant sex-differences $(p=0.663)$, including in terms of plasma Mg levels $(p=0.106)$. Females had higher TC $(p=0.006)$ and HDL-C $(p<0.001)$, lower TG $(p<0.001)$, similar LDL-C 
$(p=0.781)$ versus men. Men were more likely to suffer from obesity $(p=0.012)$, T2DM

$(p=0.039)$, hypertension $(p<0.001)$, use lipid-lowering $(p=0.040)$ or blood pressurelowering drugs $(p<0.001)$ versus females, but the prevalence of hypercholesterolemia was similar $(p=0.186)$. Mg concentrations were increased in the plasma of hypercholesteremic subjects $(p=0.001)$ and decreased in the plasma of diabetic subjects $(p=0.009)$ as compared to individuals without hypercholesterolemia or T2DM, respectively. There was a significant association between T2DM but not hypercholesterolemia and hypomagnesemia (OR: 3.36, 95\% CI: $1.26-8.96, p=0.016$ and OR: $1.38,95 \%$ CI: $0.81-2.35, p=0.233)$. However, there was an association between TC $(p=0.01)$ and LDL-C $(p=0.002)$, but HDL-C $(p=0.933)$ or TG (0.959), and plasma Mg quartiles. Furthermore, patients in the fourth versus first quartile of $\mathrm{Mg}$ concentrations were more likely to be diagnosed with hypercholesterolemia (OR: 3.12; 95\% CI: 1.66-5.85, $p$ < 0.001) [8]. Bersohn and Oelofse (1957) examined a number of forty seven healthy European and fifty three healthy African Bantu subjects. They revealed that the individuals with normal TC values had normal $\mathrm{Mg}$ values and the subjects who had a lower than normal TC had significantly higher Mg levels. Patients diagnosed with hypercholesterolemia presented significantly lower $\mathrm{Mg}$ values as compared to the healthy population [9]. Petersen et al. (1976) evaluated the 6-week intake of $3 \mathrm{~g} /$ day of $\mathrm{Mg}$ oxide in a group of seventeen patients suffering from hypercholesterolemia and/or hypertriglyceridemia in order to determine its effects on TC and TG. No significant relationship was registered between the initial values of serum Mg and TG $(r=0.05, p>0.05)$ or TC $(\mathrm{r}=-0.21, p>0.05)$. The authors discharged the hypothesis that $3 \mathrm{~g} /$ day of Mg has TC- or TG-lowering actions [10]. In a cross-sectional study, Liu et al. (2020) analyzed the relationship between $\mathrm{Mg}$ concentrations and dyslipidemia. Patients diagnosed with dyslipidemia had higher TC, TG, HDL-C, and LDL-C $(p<0.001)$ and lower Mg levels $(p=0.002)$ versus the subjects with normal serum lipids. Subjects in the fourth versus first quartile of serum $\mathrm{Mg}$ had an increased risk of dyslipidemia (OR $=1.4,95 \%$ CI 1.0-1.9, $p=0.023)$ in the unadjusted model, but this finding was not verified in the adjusted model [11].

\subsubsection{Magnesium, Serum Lipids, and the Diet/dietary Interventions}

In a retrospective analysis, Jin and Nicodemus-Johnson (2018) scrutinized 12,284 individuals from the United States' 2001-2013 National Health and Nutrition Examination Study (NHANES) and observed that, in females, Mg intake was positively associated with HDL-C levels, while it was negatively associated with the TC/HDL-C ratio. However, TG levels were negatively correlated with $\mathrm{Mg}$ intake in both genders [12]. Itoh et al. (1997) executed an RCT in which they administered Mg in 33 healthy Japanese subjects, discovering an increase in HDL-C and apoA1, as well as a significant decrease in LDL-C in the $\mathrm{Mg}$ group [13]. In Marken et al. (1989)'s RCT, the administration of $400 \mathrm{mg} \mathrm{Mg}$ oxide for 60 days to 50 healthy volunteers did not result in changes of TC, HDL-C, LDL-C, VLDL, or TG versus placebo [14]. According to Randell et al. (2008), a number of 1318 healthy individuals recruited in their study displayed significant positive correlations between $\mathrm{Mg}$ and TC, HDL-C, LDL-C, and TG [15]. In a cross-sectional study that administered Mg and potassium at variable doses in 529 healthy individuals, Guerrero-Romero et al. (2019) showed significant TG decreases $(p<0.0005)$ and no HDL-C alterations in the subjects receiving recommended versus suboptimal $\mathrm{Mg}$ doses [16]. De Valk et al. investigated the link between serum $\mathrm{Mg}$ variations and lipolysis-induced TG generation, revealing that an elevation in serum Mg was parallel by an elevation in TG as well $(p<0.001)$ [17]. Aslanabadi et al. (2014) explored the lipid-lowering effects of 1 daily liter of mineral-rich versus normal mineral water in an RCT conducted in 69 adults diagnosed with dyslipidemia (intervention group: 32 subjects, control group: 37 subjects). Despite the fact that the beverage which was enriched with $\mathrm{Mg}$, calcium, sulfate, and bicarbonate lowered TC and LDL-C, the same outcome was reported in the control group as well and there was no statistical difference between the results. Both waters failed to exhibit an impact of TG or HDL-C [18]. According to Fu et al. (2012), the consumption of deep sea water ( $395 \mathrm{Mg} \mathrm{mg} / \mathrm{L}$ ) versus $\mathrm{MgCl}_{2}$ fortified (386 Mg mg/L) or reverse osmotic water decreased TC, LDL-C, and HDL-C 
in a time-dependent manner [19]. Based on Nerbrand et al. (2003)'s research, there are no correlations between the content of $\mathrm{Mg}$ in the water and cardiovascular risk factors [20]. Luoma et al. (1973) studied the relationship of $\mathrm{Mg}$ concentrations in the drinking water with several cardiovascular risk factors (including TG and TC) in 300 men from four different Finnish rural districts, but found no association between these variables [21]. Low-energy dietary interventions which also involved $\mathrm{Mg}$ supplementation achieved reductions in $\mathrm{TC}$, LDL-C, and TG, but also decreased HDL-C, according to a pre-post intervention evaluation of 49 subjects from the United States [22]. In de Los Rios (1963)'s research project, a number of twenty eight schizophrenic patients were prescribed a strictly controlled diet which included $\mathrm{Mg}$ in quantities above the recommended dietary values, but this nutrition experiment found no association between the alterations of Mg levels and TC [23]. A higher dietary consumption of $\mathrm{Mg}$ seems to be linked with oxidized LDL, a biomarker of oxidative stress, as concluded by Cocate et al. (2013) who assessed the intake of vegetables, fruit, and nutrients of 296 middle-aged males with a normal status of health [24]. Patients with multimorbidity (including hypercholesterolemia) are known to have smaller daily intakes of $\mathrm{Mg}$, whereas an increased consumption of cereals $(\mathrm{r}=0.60, p<0.0001)$ and fruits and vegetables $(r=0.49, p<0.0001)$ were associated with higher serum $\mathrm{Mg}$ levels and less multimorbidity [25]. There seems to be an inverse correlation between the intake of $\mathrm{Mg}$ and TC in both males $(p=0.02)$ and females $(p=0.04)$, according to Bain et al. (2015) who evaluated 4443 subjects aged 40-75 from the European Prospective Investigation into Cancer)-Norfolk cohort in order to assess the relationship between the risk of stroke and its most important risk factors and the dietary consumption of $\mathrm{Mg}$ [26]. In addition, Samavarchi Tehrani et al. (2020) recorded a significant association $(p=0.012)$ between the presence of dyslipidemia and Mg levels in 447 patients suffering a stroke of embolic origin [27]. Interestingly, Kim et al. (2014), based on best-fit models from stepwise linear regressions, discovered that the dietary intake of $\mathrm{Mg}$ predicts the concentrations of HDL-C and its subspecies. In their study group of 1566 individuals, the dietary consumption of $\mathrm{Mg}$ shared positive associations with HDL-C (coefficient \pm SE: $4.79 \pm 1.45$; \%HDL-C variation: $0.12 \%, p=0.001$ ) and its subfractions, HDL-2 (coefficient \pm SE: $1.43 \pm 0.61$; \%HDL-C variation: $0.028 \%, p=0.018$ ) and HDL-3 (coefficient \pm SE: $2.98 \pm 1.20$; \%HDL-C variation: $0.085 \%, p=0.013$ ), but not with apoA1 concentrations [28]. Kim and Choi (2013) investigated the dietary intake of $\mathrm{Mg}$ and its relationship with the lipid profile in 258 healthy Korean adults. Although men had a higher $\mathrm{Mg}$ daily consumption versus women, they registered higher TG $(p<0.05)$ and lower HDL-C $(p<0.01)$ values, yet similar TC and LDL-C levels. The atherogenic index of plasma was also elevated in males versus females $(p<0.001)$. However, the correlations between serum Mg and TC, HDL-C, LDL-C, TG or the atherogenic index of plasma did not reach statistical significance [29]. Cao et al. (2015) analyzed the relationships between serum and urinary $\mathrm{Mg}$ concentrations and the lipid profile in 2837 middle-aged/elderly Chinese, revealing a positive association between higher serum Mg and TC $(p<0.001)$, HDL-C $(p<0.001)$, LDL-C $(p=0.001)$, and TG $(p<0.001)$, and negative one with non-HDL-C/HDL-C $(p=0.003)$. There were also positive associations between the $\mathrm{Mg}$ /creatinine ratio in the urine and TC $(p=0.004)$, HDL-C $(p=0.003)$, and LDL-C ( $p=0.009)$. However, there were some gender-based differences regarding these results: in males, the associations between serum Mg and LDL-C, TG or non-HDL-C/HDL$\mathrm{C}$, and those between urinary $\mathrm{Mg}$ / creatinine and HDL-C or LDL-C, were not statistically significant [30]. On the other hand, there are atomic absorption spectrophotometry studies conducted in postmenopausal females that show that $\mathrm{Mg}$ concentrations in red blood cells and not serum Mg concentrations correlate with serum TG ( $\mathrm{r}=0.287, p=0.011)$ [31] Data derived from the Cardiovascular Disease and Alimentary Comparison (CARDIAC) study also reinforced that hypercholesterolemia was more prevalent and TC concentrations were higher in individuals with lower versus higher 24-h urinary $\mathrm{Mg} /$ creatinine ratios $(p<0.001$ for trend for both). Subjects in the lowest quintiles of $24-\mathrm{h} \mathrm{Mg} /$ creatinine urinary ratios were more likely to suffer from hypercholesterolemia $(\mathrm{OR}=2.73$; 95\% CI 2.03 to 3.67; $p<0.001)$ versus the highest quintiles [32]. 


\subsubsection{Magnesium, Serum Lipids, and Overweight and (or) Obesity}

Guerrero-Romero and Rodriguez-Moran (2013) investigated the relationship between serum $\mathrm{Mg}$ and several metabolic phenotypes, namely healthy normal-weight (NW) versus metabolically obese normal weight (MONW) subjects, as well as obese versus metabolically healthy obese (MHO) patients. NW and $\mathrm{MHO}$ subjects exhibited higher serum $\mathrm{Mg}$ concentrations ( $p=0.04$ and $p=0.01$, respectively) and lower TG ( $p<0.0005$ for both), yet similar HDL-C levels, versus their corresponding comparators. In MONW patients, there was a negative correlation between TG and serum Mg ( $\mathrm{r}=-0.530$, unreported $p$-value). Moreover, in both obese and in particular non-obese patients, low serum $\mathrm{Mg}$ concentrations were associated with the presence of hypertriglyceridemia (OR $=1.61,95 \%$ CI: $1.5-2.46$ and $\mathrm{OR}=6.67,95 \%$ CI 2.1-20.4, respectively) [33]. However, $\mathrm{Mg}$ levels did not correlate with TG concentrations in another study on obese individuals who were planning to undergo bariatric surgery [34]. In Rodriguez-Moran and Guerrero-Romero (2014)'s RCT, the 4-month daily administration of $30 \mathrm{~mL}$ of $\mathrm{MgCl}_{2} 5 \%$ solution (equivalent to $382 \mathrm{mg}$ of $\mathrm{Mg}$ ) was compared to the administration of $30 \mathrm{~mL}$ of placebo solution in hypomagnesemic MONW subjects. Following the intervention, HDL-C increased $(p<0.05)$ and TG levels decreased $(p<0.0001)$ significantly [35]. In their RCT, Joris et al. (2017) examined the effect of long-term $\mathrm{Mg}$ supplementation on endothelial function and multiple cardiometabolic risk markers in subjects suffering from overweight or obesity. Fifty two subjects were assigned randomly to two different groups that received either a dose consisting of $350 \mathrm{mg} \mathrm{Mg}$ or placebo, yet no differences in TC, HDL-C, LDL-C, TG or non-esterified fatty acids were observed in the intervention versus control groups [36]. Guerrero-Romero et al. (2016) investigated the relationship between obesity and hypomagnesemia in six hundred and eighty one subjects. When separating the subjects based on their Mg levels, their findings reported a significant difference in the mean values of HDL-C $(1 \pm 0.3 \mathrm{mmol} / \mathrm{L}$ in the low serum $\mathrm{Mg}$ group and $1.2 \pm 0.4 \mathrm{mmol} / \mathrm{L}$ in the normal serum $\mathrm{Mg}$ group), as well as in TG $(1.9 \pm 1.4 \mathrm{mmol} / \mathrm{L}$ in the low serum $\mathrm{Mg}$ group and $1.8 \pm 1.5 \mathrm{mmol} / \mathrm{L}$ in the normal serum Mg group) [37]. Solati et al. (2019) executed a 6-month RCT in which they administered $300 \mathrm{mg} \mathrm{Mg}$ sulfate in the form of herbal supplements versus placebo in overweight subjects who did not suffer from T2DM. Mg administration increased HDL-C $(p<0.001)$ and HDL-C/TG $(p<0.0001)$ and lowered LDL-C $(p<0.05)$ and TG $(p<0.05)$ values [38].

Table 1. Magnesium and serum lipids interplay in patients with a normal health status and patients diagnosed with dyslipidemia or related disorders.

\begin{tabular}{|c|c|c|c|c|}
\hline Author and Year & Condition & $\begin{array}{c}\text { Number of } \\
\text { Patients }\end{array}$ & $\begin{array}{l}\text { Method of } \mathrm{Mg} \\
\text { Determination }\end{array}$ & Main Results \\
\hline Barragán et al. (2020) [8] & $\begin{array}{l}\text { Cardiometabolic risk } \\
\text { factors: T2DM, } \\
\text { hypercholesterolemia, } \\
\text { hypertension }\end{array}$ & 492 & $\begin{array}{l}\text { Serum, urine } \\
\text { (spectrometry) }\end{array}$ & $\begin{array}{c}\text { Prevalence of hypoMg }=19 \% \\
\text { Hypercholesterolemia: Mg } \uparrow \text {; T2DM: Mg } \\
\downarrow \\
\text { HypoMg-T2DM association (OR: } 3.36, \\
95 \% \text { CI: } 1.26-8.96, p=0.016) \\
\text { TC, LDL-C associated with Mg quartiles } \\
\uparrow \text { Hypercholesterolemia in } 4 \text { th versus 1st } \\
\text { quartile of Mg levels (OR: } 3.12 ; 95 \% \text { CI: } \\
1.66-5.85, p<0.001 \text { ) }\end{array}$ \\
\hline $\begin{array}{l}\text { Bersohn and Oelofse } \\
\text { (1957) [9] }\end{array}$ & Healthy & 100 & $\begin{array}{l}\text { Serum } \\
\text { (spectrophotometry) }\end{array}$ & $\begin{array}{c}\text { Normal TC-normal Mg } \\
\downarrow \text { TC- } \uparrow \mathrm{Mg} \\
\text { Hypercholesterolemia: } \downarrow \text { Mg }\end{array}$ \\
\hline Petersen et al. (1976) [10] & $\begin{array}{l}\text { Hypercholesterolemia } \\
\text { Hypertriglyceridemia }\end{array}$ & 17 & $\begin{array}{c}\text { Serum } \\
\text { (spectrophotometry) }\end{array}$ & $\begin{array}{c}3 \mathrm{~g} / \text { day of } \mathrm{MgO} \text { for } 6 \text { weeks: no effect on } \\
\text { TC, TG }\end{array}$ \\
\hline Liu et al. (2020) [11] & Dyslipidemia & 1466 & $\begin{array}{c}\text { Serum } \\
\text { (spectrophotometry) }\end{array}$ & $\begin{array}{c}\uparrow \mathrm{TC}, \mathrm{TG}, \mathrm{HDL}-\mathrm{C} \text { and LDL-C }(p<0.001) \\
\downarrow \mathrm{Mg}(p=0.002) \\
\uparrow \text { Dyslipidemia in the } 4 \text { th versus } 1 \text { st } \mathrm{Mg} \\
\text { quartile (OR }=1.4,95 \% \text { CI } 1.0-1.9, \\
p=0.023)\end{array}$ \\
\hline
\end{tabular}


Table 1. Cont.

\begin{tabular}{|c|c|c|c|c|}
\hline Author and Year & Condition & $\begin{array}{c}\text { Number of } \\
\text { Patients }\end{array}$ & $\begin{array}{l}\text { Method of } \mathrm{Mg} \\
\text { Determination }\end{array}$ & Main Results \\
\hline $\begin{array}{l}\text { Jin and } \\
\text { Nicodemus-Johnson (2018) } \\
\text { [12] }\end{array}$ & Healthy & 12,284 & $\begin{array}{l}\text { Serum } \\
\text { (method unspecified) }\end{array}$ & $\begin{array}{c}\text { (+) association of } \mathrm{Mg} \text { intake and HDL-C } \\
\text { in } q \\
(-) \text { association of } \mathrm{Mg} \text { intake and } \\
\mathrm{TC} / \mathrm{HDL}-\mathrm{C} \text { ratio in } \uparrow \\
(-) \text { association of } \mathrm{Mg} \text { intake and TG in } \\
\text { o and } \sigma^{7}\end{array}$ \\
\hline Randell et al. (2008) [15] & Healthy & 1318 & $\begin{array}{c}\text { Serum } \\
\text { (spectroscopy) }\end{array}$ & $\begin{array}{c}\text { (+) association of } \mathrm{Mg} \text { and TC, HDL-C, } \\
\text { LDL-C, TG }\end{array}$ \\
\hline $\begin{array}{l}\text { Guerrero-Romero et al. } \\
\text { (2019) [16] }\end{array}$ & Healthy & 529 & $\begin{array}{c}\text { Serum } \\
\text { (method unspecified) }\end{array}$ & Mg and K supplementation $\downarrow$ TG \\
\hline Fu et al. (2012) [19] & Healthy & 42 & $\begin{array}{l}\text { Serum } \\
\text { (method unspecified) }\end{array}$ & $\begin{array}{c}\text { deep sea water ( } 395 \mathrm{Mg} \mathrm{mg} / \mathrm{L}) \downarrow \mathrm{TC} \text {, } \\
\mathrm{LDL}-\mathrm{C} \text { and HDL-C } \\
\text { versus } \mathrm{MgCl}_{2} \text { fortified (386 Mg mg/L) or } \\
\text { reverse osmotic water }\end{array}$ \\
\hline Nerbrand et al. (2003) [20] & $\mathrm{CV}$ risk factors & 207 & $\begin{array}{l}\text { Serum, whole blood, } \\
\text { muscle, urine } \\
\text { (method unspecified) }\end{array}$ & $\begin{array}{l}\text { No correlation of } \mathrm{Mg} \text { content in water } \\
\text { and } \mathrm{CV} \text { risk factors }\end{array}$ \\
\hline Luoma et al. (1973) [21] & $\mathrm{CV}$ risk factors & 300 & $\begin{array}{c}\text { Serum } \\
\text { (method unspecified) }\end{array}$ & $\begin{array}{l}\text { No correlation of } \mathrm{Mg} \text { in drinking water } \\
\text { and CV risk factors (TG, TC) }\end{array}$ \\
\hline Balliett et al. (2013) [22] & Healthy & 49 & $\begin{array}{c}\text { Serum } \\
\text { (method unspecified) }\end{array}$ & $\begin{array}{c}\text { Low-energy dietary interventions }(+\mathrm{Mg}) \\
\quad \downarrow \mathrm{TC}, \mathrm{LDL}-\mathrm{C}, \mathrm{TG} \text { and HDL-C }\end{array}$ \\
\hline de Los Rios (1963) [23] & Schizophrenia & 28 & $\begin{array}{c}\text { Serum } \\
\text { (method unspecified) }\end{array}$ & $\begin{array}{l}\text { Controlled diet }(\mathrm{Mg}>\mathrm{RDV}): \text { no } \\
\text { associations of } \Delta \mathrm{TC} \text { and } \Delta \mathrm{Mg}\end{array}$ \\
\hline Cocate et al. (2013) [24] & Healthy & 296 & $\begin{array}{c}\text { Serum } \\
\text { (method unspecified) }\end{array}$ & Association of $\uparrow \mathrm{Mg}$ intake and oxLDL \\
\hline Ruel et al. (2014) [25] & $\begin{array}{c}\text { Multimorbidity, } \\
\text { Hypercholesterolemia }\end{array}$ & 1020 & $\begin{array}{l}\text { Serum } \\
\text { (method unspecified) }\end{array}$ & $\begin{array}{c}\uparrow \text { consumption of cereals }(\mathrm{r}=0.60, \\
p<0.0001), \text { fruits and vegetables }(\mathrm{r}=0.49, \\
p<0.0001) \text { associated with } \uparrow \mathrm{Mg} \text { and } \downarrow \\
\text { multimorbidity }\end{array}$ \\
\hline Bain et al. (2015) [26] & Healthy & 4443 & $\begin{array}{c}\text { Serum } \\
\text { (method unspecified) }\end{array}$ & $\begin{array}{l}\text { Inverse correlation of } \mathrm{Mg} \text { intake and TC } \\
\text { in } \sigma^{\top}(p=0.02) \text { and } q(p=0.04)\end{array}$ \\
\hline $\begin{array}{l}\text { Samavarchi Tehrani et al. } \\
\text { (2020) [27] }\end{array}$ & Dyslipidemia & 447 & $\begin{array}{c}\text { Serum } \\
\text { (method unspecified) }\end{array}$ & $\begin{array}{l}\text { Mg levels associated with dyslipidemia } \\
\text { in embolic stroke }(p=0.012)\end{array}$ \\
\hline Kim et al. (2014) [28] & Healthy & 1566 & $\begin{array}{l}\text { Serum } \\
\text { (method unspecified) }\end{array}$ & $\begin{array}{c}(+) \text { association of } \mathrm{Mg} \text { intake and HDL-C } \\
(p=0.001), \mathrm{HDL}-2(p=0.018), \mathrm{HDL}-3 \\
(p=0.013)\end{array}$ \\
\hline Kim and Choi (2013) [29] & Healthy & 258 & $\begin{array}{c}\text { Serum } \\
\text { (method unspecified) }\end{array}$ & $\begin{array}{c}\uparrow \mathrm{Mg} \text { intake, } \uparrow \mathrm{TG}(p<0.05), \downarrow \text { HDL-C } \\
(p<0.01), \uparrow \operatorname{AIP}(p<0.001) \text { in } \sigma^{\Uparrow}\end{array}$ \\
\hline Cao et al. (2015) [30] & Healthy & 2837 & $\begin{array}{c}\text { Serum, urine } \\
\text { (method unspecified) }\end{array}$ & $\begin{array}{c}\text { (+) association of } \uparrow \text { serum Mg and TC } \\
(p<0.001), \mathrm{HDL}-\mathrm{C}(p<0.001), \mathrm{LDL}-\mathrm{C} \\
(p=0.001), \mathrm{TG}(p<0.001) \\
(-) \text { association of } \uparrow \text { serum Mg and } \\
\text { non-HDL-C } / \mathrm{HDL}-\mathrm{C}(p=0.003) \\
(+) \text { association of Mg/creatinine ratio in } \\
\text { urine and TC }(p=0.004), \text { HDL-C } \\
(p=0.003) \text { and LDL-C }(p=0.009)\end{array}$ \\
\hline $\begin{array}{l}\text { López-González et al. } \\
\text { (2014) [31] }\end{array}$ & Post-menopause & 78 & $\begin{array}{c}\text { Serum } \\
\text { (method unspecified) }\end{array}$ & $\begin{array}{l}\mathrm{Mg} \text { in red blood cells, not serum } \mathrm{Mg} \text {, } \\
\text { correlates with TG }(\mathrm{r}=0.287, p=0.011)\end{array}$ \\
\hline Yamori et al. [32] & Hypercholesterolemia & 4211 & $\begin{array}{c}\text { Serum, urine } \\
\text { (method unspecified) }\end{array}$ & $\begin{array}{c}\uparrow \text { hypercholesterolemia, } \uparrow \mathrm{TC} \text { in lower } \\
\text { versus higher } 24-\mathrm{h} \text { urinary } \\
\mathrm{Mg} / \text { creatinine ratios }(p<0.001 \text { for trend } \\
\text { for both) } \\
\uparrow \text { hypercholesterolemia in the lowest } \\
\text { versus the highest quintiles of } 24-\mathrm{h} \\
\mathrm{Mg} / \text { creatinine urinary ratios (OR }=2.73 \text {; } \\
95 \% \mathrm{CI} 2.03 \text { to } 3.67 ; p<0.001)\end{array}$ \\
\hline $\begin{array}{c}\text { Guerrero-Romero and } \\
\text { Rodriguez-Moran (2013) } \\
\text { [33] }\end{array}$ & Overweight/obesity & 427 & $\begin{array}{l}\text { Serum } \\
\text { (method unspecified) }\end{array}$ & $\begin{array}{c}\text { NW and MHO: } \uparrow \mathrm{Mg}(p=0.04 \text { and } \\
p=0.01 \text {, respectively), } \downarrow \text { TG }(p<0.0005 \\
\text { for both) } \\
\text { MONW: }(-) \text { Mg-TG correlation } \\
\text { Obese and non-obese: } \downarrow \text { Mg associated } \\
\text { with hypertriglyceridemia (OR }=1.61, \\
95 \% \text { CI: } 1.5-2.46 \text { and OR }=6.67,95 \% \text { CI } \\
\text { 2.1-20.4, respectively) }\end{array}$ \\
\hline
\end{tabular}


Table 1. Cont.

\begin{tabular}{|c|c|c|c|c|}
\hline Author and Year & Condition & $\begin{array}{l}\text { Number of } \\
\text { Patients }\end{array}$ & $\begin{array}{l}\text { Method of } \mathrm{Mg} \\
\text { Determination }\end{array}$ & Main Results \\
\hline Lefebvre et al. (2014) [34] & Obesity & 267 & $\begin{array}{c}\text { Serum } \\
\text { (method unspecified) }\end{array}$ & $\begin{array}{c}\text { No Mg-TG correlation in candidates for } \\
\text { bariatric surgery }\end{array}$ \\
\hline $\begin{array}{l}\text { Guerrero-Romero et al. } \\
\text { (2016) [37] }\end{array}$ & Obesity & 681 & $\begin{array}{c}\text { Serum } \\
\text { (method unspecified) }\end{array}$ & $\begin{array}{c}\downarrow \mathrm{HDL}-\mathrm{C}, \uparrow \mathrm{TG} \text { in } \downarrow \text { Mg versus normal } \\
\mathrm{Mg} \text { groups }\end{array}$ \\
\hline $\begin{array}{l}\text { Farsinejad-Marj et al. } \\
\text { (2020) [39] }\end{array}$ & PCOS & 60 & $\begin{array}{l}\text { Serum } \\
\text { (method unspecified) }\end{array}$ & $\begin{array}{c}250 \mathrm{mg} / \text { day Mg oxide for } 8 \text { weeks: no } \\
\text { effect on TC, HDL-C, LDL-C, TG, } \\
\text { TC/HDL-C, TG/HDL-C }\end{array}$ \\
\hline Cutler et al. (2019) [40] & PCOS & 137 & $\begin{array}{c}\text { Serum } \\
\text { (method unspecified) }\end{array}$ & $\begin{array}{c}\text { Mg-rich diet } \downarrow \text { insulin resistance and } \uparrow \\
\text { HDL-C ( } p=0.02 \text { for both) }\end{array}$ \\
\hline
\end{tabular}

$\mathrm{Mg}$, magnesium. T2DM, type 2 diabetes mellitus. CV, cardiovascular. PCOS, polycystic ovary syndrome. hypoMg, hypomagnesemia. OR,

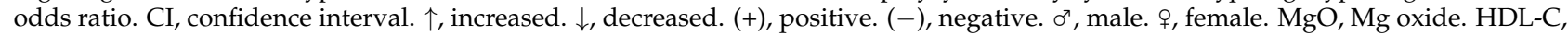
high-density lipoprotein cholesterol. LDL-C, low-density lipoprotein cholesterol. TC, total cholesterol. TG, triglycerides. VLDL, very lowdensity lipoprotein cholesterol. apoA1, apolipoprotein A1. oxLDL, oxidized LDL. RDV, recommended dietary value. $\Delta$, variation. $\mathrm{MgCl}_{2}$, Mg chloride. mg, milligrams. g, grams. mL, milliliter. K, potassium. MONW, metabolically obese normal-weight. NW, normal weight.

\subsubsection{Magnesium, Serum Lipids, and Polycystic Ovary Syndrome (PCOS)}

$\mathrm{Mg}$ supplementation ( $250 \mathrm{mg} /$ day $\mathrm{Mg}$ oxide for 8 weeks) in females with polycystic ovary syndrome did not lead to significant changes in TC, HDL-C, LDL-C, TG, TC/HDL-C, or TG/HDL-C versus placebo [39]. Cutler et al. (2019) inspected the nutritional intakes of 87 women with PCOS and reported that females following a Mg-rich diet had less insulin resistance $(p=0.02)$ and higher HDL-C $(p=0.02)$ [40]. In Jamilian et al. (2019)'s RCT, 60 women with PCOS who received $\mathrm{Mg}+$ vitamin $\mathrm{E}$ displayed significant reductions in TG $(p=0.001)$ and VLDL $(p=0.01)$, but no alterations in LDL-C, HDL-C, or TC/HDLC [41]. Moreover, in another RCT, Jamilian et al. (2017), TG $(p<0.001)$, VLDL $(p<0.001)$, and TC $(p=0.04)$ decreased significantly, but significant effect on LDL-C or HDL-C was seen in the 60 women with PCOS that received Mg, zinc, calcium, and vitamin D cosupplementation [42].

\subsubsection{Magnesium, Serum Lipids, and Nonalcoholic Fatty Liver Disease (NAFLD)}

Karandish et al. (2013) conducted an RCT in 34 NAFLD subjects versus 34 healthy controls in which they investigated the benefits of $\mathrm{Mg}$ supplementation in combination with a low-calorie diet and physical exercise on several biochemical parameters. NAFDL patients who received the intervention consisting in supplementation with $\mathrm{Mg}$ did not experience statistically significant alterations of TC, LDL-C, HDL-C, or TG concentrations, whereas LDL-C $(p=0.000)$ and TC $(p=0.003)$ concentrations dropped significantly in the control group who did not receive $\mathrm{Mg}$ and only practiced physical exercise and caloric restriction [43].

\subsection{Crosstalk of Magnesium, Serum Lipids, and Metabolic Syndrome}

A total of 16 studies assessed the crosstalk of Mg, serum lipids, and MetS, focusing on the relationship of serum $\mathrm{Mg}$ with the lipid profile in this metabolic disorder, including the impact of dietary $\mathrm{Mg}$ intake or $\mathrm{Mg}$ supplementation on serum lipids.

Ali et al. (2013) investigated the dietary intakes of 213 American Indians diagnosed with MetS who were enrolled into the Balance Study RCT. The authors detected that nearly $90 \%$ of the male subjects had $\mathrm{Mg}$ intakes below the daily recommended dose, mainly due to dietary patterns poor in whole grains and vegetables which are sources of $\mathrm{Mg}$ [44]. Similarly, Vajdi et al. (2020) reported that subjects who follow a nutrient pattern based on plant sources which is also rich in Mg depict lower odds of MetS $(p=0.01)$ and lower LDL-C ( $p=0.04)$, but similar TC, TG, and HDL-C ( $p>0.05$ for all) when comparing the first to the fourth quartile of this diet [45]. However, Akbarzade et al. (2020) did not detect an association between a nutrient pattern which comprised a higher $\mathrm{Mg}$ intake and MetS components in Iranian adults [46]. Similarly, Mottaghian et al. (2020) did not discover any association between the Mg-rich dietary pattern and alterations of the serum lipids 
during a 3-year timeframe. Nevertheless, TG increased ( $p<0.05$ for trend) across the quartiles of the Mg-rich nutrient pattern [47]. Choi and Bae (2013) evaluated the intake of $\mathrm{Mg}$ and the risk of MetS in Korean adults, revealing that both males and females diagnosed with MetS had lower Mg intakes and percentages of the recommended nutrient intake of intake versus healthy controls. Moreover, nearly a half of the MetS subjects did not achieve the estimated average requirement of $\mathrm{Mg}$. However, the authors did not detect a link between the risk of MetS and the intake of $\mathrm{Mg}$ after adjusting for potential confounders. Women with low HDL-C concentrations had a lower Mg consumption, yet the same finding was not verified in men. In both genders, higher TG levels could not be linked to $\mathrm{Mg}$ intakes [48]. Cano-Ibáñez et al. (2019) investigated the relationship between MetS and $\mathrm{Mg}$ concentrations in 6646 individuals and discovered that subjects with MetS have a lower dietary $\mathrm{Mg}$ intake. Low levels of education and male sex were linked with smaller dietary intakes of this nutrient [49]. Choi et al. (2014) detected no differences between MetS subjects and healthy controls in terms of serum Mg levels. However, when analyzing the hair mineral concentrations, they detected lower Mg concentrations $(p=0.046)$ and a higher sodium/magnesium ratio $(p=0.013)$ in MetS patients. Moreover, there was negative significant correlation between hair Mg and TG $(\mathrm{r}=-0.125, p<0.05)$ and positive non-significant Mg-HDL-C correlation ( $r=0.093, p>0.05)$ [50]. Vanaelst et al. (2012) also analyzed hair $\mathrm{Mg}$ levels and depicted negative correlations between serum $\mathrm{Mg}$ and non-HDL-C $(\mathrm{r}=-0.170, p=0.030)$ and metabolic score $(\mathrm{r}=-0.257, p=0.001)$ in Belgian schoolgirls. Hair Mg concentrations were significantly lower $(p=0.015)$ in females with a metabolic score of more than 3 points [51]. However, Sun et al. (2013) detected lower $\mathrm{Mg}$ $(p<0.001)$ and HDL-C and higher TC, TG, and LDL-C levels in Chinese subjects with MetS versus controls [52]. Despite low serum and intramononuclear levels of $\mathrm{Mg}$ in non-diabetic females diagnosed with MetS, de Lourdes Lima de Souza e Silva (2014) did not register any changes in TG, TC, HDL-C, or LDL-C following supplementation with $400 \mathrm{mg}$ of $\mathrm{Mg}$ chelate versus placebo in their 12-week RCT [53]. Rotter et al. (2015) evaluated the concentrations of heavy metals and bioelements in 313 Polish men aged 50-75 years and detected lower Mg levels in patients diagnosed with MetS $(p=0.02), \mathrm{T} 2 \mathrm{DM}(p=0.0001)$, and hypertension $(p=0.0001)$. Overweight/obese and normal-weight individuals had similar $\mathrm{Mg}$ concentrations $(p=0.41)$. The authors depicted positive associations between $\mathrm{Mg}$ and TC $(\mathrm{r}=0.25 ; p<0.001)$ and LDL-C $(\mathrm{r}=0.26 ; p<0.001)$, however the Mg-HDL-C or Mg-TG correlations did not reach statistical significance [54]. Ghasemi et al. (2010) retrospectively analyzed 137 individuals aged $>60$ years and unmasked that patients with MetS, T2DM and hyperglycemia depict lower Mg levels [55]. Evangelopoulos et al. (2008) also exposed that $\mathrm{Mg}$ was positively correlated with HDL-C $(\mathrm{r}=0.18 ; p=0.05)$ in patients affected by MetS [56]. In a population-based research (192 MetS subjects versus 384 healthy controls), Guerrero-Romero and Rodríguez-Morán (2002) observed a strong connection of MetS dyslipidemia and Mg deficiency based on the Mg-HDL-C $(\mathrm{r}=0.36, p<0.05), \mathrm{Mg}-\mathrm{TC}(\mathrm{r}=-0.29, p<0.05)$ associations [57]. Yuan et al. (2016) found multiple statistically significant correlations between serum $\mathrm{Mg}$, calcium, $\mathrm{Ca} / \mathrm{Mg}$ levels and metabolic risk factors for MetS. Their study included two hundred and four MetS patients and two hundred and four healthy subjects as the control group. Multiple blood tests were performed and the values of serum $\mathrm{Mg}$ and blood lipids were determined. Correlation studies were performed and the following results were described: positive correlation between serum Mg and BMI $(\mathrm{r}=0.128, p<0.05), \mathrm{TC}(\mathrm{r}=0.254, p<0.05)$, and LDL-C $(r=0.280, p<0.05)$ [58]. Rotter et al. (2016) observed statistically significant, positive correlations between Mg and TC $(r=0.25, p<0.0001)$ and LDL-C $(r=0.26, p<0.0001)$. Their results found no statistically significant correlations between Mg and HDL-C ( $\mathrm{r}=0.009$, $p=0.87)$ or TG $(r=-0.06, p=0.28)$. Three hundred and thirteen men were involved in their research which had the objective of determining the relationship between serum $\mathrm{Mg}$ concentrations and the occurrence of metabolic and/or hormonal disorders [59].

The most relevant information of this subsection are summarized in Table 2. 
Table 2. Magnesium and serum lipids interplay in MetS.

\begin{tabular}{|c|c|c|c|}
\hline Author and Year & $\begin{array}{l}\text { Number of } \\
\text { Patients }\end{array}$ & $\begin{array}{l}\text { Method of Mg } \\
\text { Determination }\end{array}$ & Main Results \\
\hline Ali et al. (2013) [44] & 213 & Unspecified & $\begin{array}{c}90 \% \text { o }{ }^{7} \mathrm{Mg} \text { intake }<\text { daily recommended dose }(\downarrow \text { whole } \\
\text { grains, vegetable intake })\end{array}$ \\
\hline Vajdi et al. (2020) [45] & 588 & Unspecified & $\begin{array}{l}\downarrow \text { odds of MetS }(p=0.01), \downarrow \text { LDL-C }(p=0.04) \text {, in the } 1 \text { st } \\
\text { versus } 4 \text { th quartile of plant source-based diets }(\uparrow \mathrm{Mg})\end{array}$ \\
\hline Akbarzade et al. (2020) [46] & 850 & Unspecified & $\begin{array}{l}\text { No association of nutrient patterns with } \uparrow \mathrm{Mg} \text { intake } \\
\text { and MetS components }\end{array}$ \\
\hline Mottaghian et al. (2020) [47] & 1637 & Unspecified & $\begin{array}{l}\text { No association of Mg-rich dietary pattern and lipid } \\
\text { profile changes } \\
\uparrow \mathrm{TG}(p<0.05 \text { for trend) across the quartiles of the } \\
\text { Mg-rich nutrient pattern }\end{array}$ \\
\hline Choi and Bae (2013) [48] & 5136 & Unspecified & $\begin{array}{c}\text { कand } \sigma^{\top}: \downarrow \mathrm{Mg} \text { intake, no link with MetS } \\
\text { \&with } \downarrow \text { HDL-C: } \downarrow \text { Mg intake } \\
\text { qand } \sigma^{\top} \text { with } \uparrow \mathrm{TG} \text { : no link with Mg intake }\end{array}$ \\
\hline Cano-Ibáñez et al. (2019) [49] & 6646 & Unspecified & $\begin{array}{c}\text { MetS: } \downarrow \text { Mg intake } \\
\downarrow \mathrm{Mg} \text { intake in } \mathrm{o}^{\top} \text { and } \downarrow \text { education }\end{array}$ \\
\hline Choi et al. (2014) [50] & 456 & $\begin{array}{l}\text { Serum } \\
\text { (automatic analytical } \\
\text { analyzer) }\end{array}$ & $\begin{array}{l}\text { serum Mg similar in MetS versus controls } \\
\downarrow \text { hair Mg levels }(p=0.046) \uparrow \mathrm{Na} / \mathrm{Mg} \text { ratio }(p=0.013) \text { in } \\
\qquad \begin{array}{c}\text { MetS } \\
(-) \text { correlation of hair Mg and TG }(\mathrm{r}=-0.125, p<0.05)\end{array}\end{array}$ \\
\hline Vanaelst et al. (2012) [51] & 166 & Unspecified & $\begin{array}{l}\quad(-) \text { correlations of serum } \mathrm{Mg} \text { and non-HDL-C } \\
\quad(\mathrm{r}=-0.170, p=0.030), \text { metabolic score }(\mathrm{r}=-0.257, \\
\quad p=0.001) \\
\downarrow \text { hair } \mathrm{Mg}(p=0.015) \text { in } \text { +with metabolic score }>3 \text { points }\end{array}$ \\
\hline Sun et al. (2013) [52] & 7641 & $\begin{array}{c}\text { Serum } \\
\text { (biochemical analyzer) }\end{array}$ & $\downarrow \mathrm{Mg}(p<0.001), \downarrow$ HDL-C, $\uparrow \mathrm{TC}, \uparrow \mathrm{TG}, \uparrow \mathrm{LDL}-\mathrm{C}$ \\
\hline Rotter et al. (2015) [54] & 313 & $\begin{array}{l}\text { Serum and whole } \\
\text { blood } \\
\text { (spectrometry) }\end{array}$ & $\begin{array}{l}\downarrow \mathrm{Mg} \text { in MetS }(p=0.02), \mathrm{T} 2 \mathrm{DM}(p=0.0001), \mathrm{HTN} \\
(p=0.0001) \\
(+) \text { associations of } \mathrm{Mg} \text { and TC }(\mathrm{r}=0.25 ; p<0.001) \\
\text { LDL-C }(\mathrm{r}=0.26 ; p<0.001)\end{array}$ \\
\hline Ghasemi et al. (2010) [55] & 137 & $\begin{array}{c}\text { Serum } \\
\text { (spectrometry) }\end{array}$ & $\begin{array}{c}\downarrow \mathrm{Mg} \text { in patients }>60 \text { years with MetS, T2DM and } \\
\text { hyperglycemia }\end{array}$ \\
\hline $\begin{array}{l}\text { Evangelopoulos et al. (2008) } \\
\text { [56] }\end{array}$ & 117 & $\begin{array}{c}\text { Serum } \\
\text { (colorimetric reaction) }\end{array}$ & (+) Mg-HDL-C association $(\mathrm{r}=0.18 ; p=0.05)$ \\
\hline $\begin{array}{l}\text { Guerrero-Romero and } \\
\text { Rodríguez-Morán (2002) [57] }\end{array}$ & 576 & $\begin{array}{c}\text { Serum } \\
\text { (colorimetric assay) }\end{array}$ & $\begin{array}{l}\text { (+) Mg-HDL-C association }(\mathrm{r}=0.36, p<0.05) \\
(-) \mathrm{Mg}-\mathrm{TC} \text { association }(\mathrm{r}=-0.29, p<0.05)\end{array}$ \\
\hline Yuan et al. (2016) [58] & 408 & $\begin{array}{c}\text { Serum } \\
\text { (spectrometry) }\end{array}$ & $\begin{array}{l}\text { (+) correlations: } \mathrm{Mg} \text {-BMI }(\mathrm{r}=0.128, p<0.05), \mathrm{Mg}-\mathrm{TC} \\
(\mathrm{r}=0.254, p<0.05), \mathrm{Mg}-\mathrm{LDL}-\mathrm{C}(\mathrm{r}=0.280, p<0.05)\end{array}$ \\
\hline Rotter et al. (2016) [59] & 313 & $\begin{array}{l}\text { Serum } \\
\text { (spectrometry) }\end{array}$ & $\begin{array}{c}(+) \text { correlations: } \mathrm{Mg}-\mathrm{TC}(\mathrm{r}=0.25, p<0.0001), \mathrm{Mg}-\mathrm{LDL}-\mathrm{C} \\
(\mathrm{r}=0.26, p<0.0001)\end{array}$ \\
\hline
\end{tabular}

$\mathrm{Mg}$, magnesium. MetS, metabolic syndrome. T2DM, type 2 diabetes mellitus. HTN, hypertension. hypoMg, hypomagnesemia. OR, odds ratio. CI, confidence interval. $\uparrow$, increased. $\downarrow$, decreased. (+), positive. (-), negative. $\diamond^{\prime}$, male. $\uparrow$, female. MgO, Mg oxide. HDL-C, highdensity lipoprotein cholesterol. LDL-C, low-density lipoprotein cholesterol. TC, total cholesterol. TG, triglycerides. VLDL, very low-density lipoprotein cholesterol. apoA1, apolipoprotein A1. oxLDL, oxidized LDL. RDV, recommended dietary value. $\Delta$, variation. $\mathrm{MgCl}_{2}, \mathrm{Mg}$ chloride. mg, milligrams. g, grams. $\mathrm{mL}$, milliliter. $\mathrm{K}$, potassium. MONW, metabolically obese normal-weight. NW, normal weight.

\subsection{Magnesium, Serum Lipids, and Type 2 Diabetes Mellitus (T2DM)}

A total of 40 studies assessed the crosstalk of $\mathrm{Mg}$, serum lipids, and T2DM, focusing on the relationship of serum $\mathrm{Mg}$ with the lipid profile in this metabolic disorder, including the impact of dietary $\mathrm{Mg}$ intake or $\mathrm{Mg}$ supplementation on serum lipids. The associations of hypomagnesemia with the lipid profile was evaluated in eight papers, whereas the benefits of $\mathrm{Mg}$ supplementation (data mostly derived from RCTs) was scrutinized in 21 manuscripts. 
Based on data from 5568 subjects enrolled in the Prevention of Renal and Vascular Endstage Disease (PREVEND) study, van Dijk et al. (2019) unveiled that Mg levels (assessed by both nuclear magnetic resonance spectroscopy and colorimetric assays) are lower in T2DM $(p<0.001$ for both methods). In the entire study population, there was a negative correlation between $\mathrm{Mg}$ (measured by nuclear magnetic resonance spectroscopy but not colorimetric assays) and TG ( $\mathrm{r}=-0.073, p<0.001$ and $\mathrm{r} \leq 0.001, p=0.99$, respectively). In T2DM subjects, there was a negative correlation of $\mathrm{Mg}$ (measured by nuclear magnetic resonance spectroscopy and colorimetric assays) and TG $(r=-0.184, p=0.002$ and $r=-0.194$, $p=0.001$, respectively). In the entire study population, according to the results of the multivariable linear regression, there was a correlation between $\mathrm{Mg}$ (measured by nuclear magnetic resonance spectroscopy) and low HDL-C concentrations $(\beta=-0.062, p<0.001)$, but not with high TG concentrations $(\beta=-0.011, p=0.45)$. There was no association between Mg levels measured by colorimetric assays and HDL-C or TG [60]. As compared to healthy controls, Rusu et al. (2013) demonstrated that T2DM patients, and particularly those suffering from peripheral arterial disease, have lower $\mathrm{Mg}(p<0.01)$ and HDL$\mathrm{C}$ and higher TG and TC levels [61]. Spiga et al. (2019) evaluated the associations of $\mathrm{Mg}$ concentrations and serum lipids in patients with impaired fasting glucose or T2DM. $\mathrm{Mg}$ and HDL-C levels decreased and TG increased as follows: patients with normal glucose tolerance $\rightarrow$ impaired fasting glucose $\rightarrow$ T2DM $(p<0.02, p<0.01$ and $p<0.001$, respectively). Significant correlations of Mg with TC $(r=0.154, p<0.001)$, HDL-C $(r=0.113$, $p<0.01)$, LDL-C $(\mathrm{r}=0.170, p<0.001)$, but not with TG $(\mathrm{r}=0.01, p=0.981)$. Higher Mg concentrations were linked with a lower risk of T2DM (OR $=0.765,95 \%$ CI $0.629-0.932$, $p<0.01$ ), including in the non-diabetic subjects who were followed-up for nearly 6 years (HR $=0.790,95 \%$ CI: 0.645-0.967; $p=0.022$ ) [62]. Esmeralda et al. (2021) investigated the link between TC, TG and serum/urinary Mg in T2DM versus healthy counterparts. T2DM subjects had higher TG $(p=0.004)$ and fractional excretion of $\mathrm{Mg}(p=0.01)$, lower serum $\operatorname{Mg}(p=0.001)$ and similar TC $(p=0.31)$ and urinary $\operatorname{Mg}(p=0.097)$ versus controls. Nevertheless, no associations of the serum $\mathrm{Mg}$ or the fractional excretion of $\mathrm{Mg}$ with TC or TG were detected [63]. Gopal et al. (2019) concluded that serum Mg concentrations predict the development of proliferative retinopathy in patients with T2DM (optimum cut-off $1.7 \mathrm{mg} / \mathrm{dL}$, sensitivity $92.86 \%$, specificity $77.14 \%$, AUC 0.837, SEM $0.06,95 \%$ CI $0.70-0.92)$. In T2DM, Mg levels decreased as following no retinopathy $\rightarrow$ non-proliferative retinopathy $\rightarrow$ proliferative retinopathy $(p<0.01)$. Surprisingly, patients with proliferative retinopathy had higher HDL-C values $(p<0.05)$. TC, TG, LDL-C, and VLDL concentrations did not differ significantly among the study groups [64]. Hruby et al. (2017) studied the link between the intake of $\mathrm{Mg}$ and the risk of T2DM in three cohorts from the United States of America, detecting a 15\% T2DM-risk reduction in individuals with a higher dietary intake of $\mathrm{Mg}$. Hypercholesterolemia was more frequent in the fifth (12.7\% for $427-498 \mathrm{mg} /$ day) versus first ( $8.7 \%$ for $242-275 \mathrm{mg}$ /day) quartile of Mg intake, whereas in women the data were conflicting: in one cohort, hypercholesterolemia was more prevalent in the fifth $(7.8 \%$ for $357-418 \mathrm{mg}$ / day) versus first (6.2\% for $187-218 \mathrm{mg}$ /day) quartile of $\mathrm{Mg}$ intake, whereas in the other cohort the results were opposite ( $15.4 \%$ for $213-245 \mathrm{mg}$ /day versus $14.4 \%$ for $385-448 \mathrm{mg} /$ day) [65]. In Anetor et al. (2002)'s research on 40 T2DM patients from Nigeria, only TC displayed a significant positive correlation with Mg levels $(\mathrm{r}=0.6 ; p<0.001)$ [66]. Corica et al. (2006) analyzed $290 \mathrm{~T} 2 \mathrm{DM}$ and detected that serum Mg was significantly lower in individuals with low HDL-C $(p<0.001)$ and high TG $(p<0.001)$ [67]. Romero and Moran (2000) evaluated 180 subjects with impaired glucose regulation (un/controlled T2DM and IFG) versus 190 healthy controls and demonstrated that decreased Mg levels are associated with decreased HDL-C, regardless of blood glucose values ( $p=0.01$ for the T2DM groups, $p=0.05$ for the IFG group and $p=0.03$ for the control group) [68]. Yu et al. (2018) reported that a group of 8163 Chinese T2DM adults, classified based on $\mathrm{Mg}$ levels, exhibited significant elevations in serum lipids, except for HDL-C, across progressive concentrations of serum $\mathrm{Mg}$ (from low Mg levels of $\leq 0.65 \mathrm{mmol} / \mathrm{L}$ normal levels $0.65-0.95 \mathrm{mmol} / \mathrm{L}$, high levels $\geq 0.95 \mathrm{mmol} / \mathrm{L})(p<0.05)$, regardless of whether 
they suffered from central obesity or not. The generalized linear model showed that after the full adjustment for demographic characteristics, lifestyle, dietary, and clinical factors, TG, TC, HDL-C, and LDL-C were significantly higher in subjects with Mg levels $\geq 0.95 \mathrm{mmol} / \mathrm{L}$ versus those with lower Mg levels $(p<0.05)$ [69]. Kurstjens et al. (2016) investigated the determinants of serum $\mathrm{Mg}$ levels in a T2DM cohort $(\mathrm{n}=395)$. Multiple blood parameters were investigated including serum Mg levels, HDL-C, LDL-C, TC, TG, and others, and correlation studies were performed. Their results showed a statistically significant negative correlation between TG and serum $\mathrm{Mg}(\mathrm{r}=-0.273, p<0.001)$, as well as a positive correlation between HDL-C and $\mathrm{Mg}(\mathrm{r}=0.156, p=0.002)$ [70].

The most relevant information of this subsection are summarized in Table 3.

Table 3. Magnesium and serum lipids interplay in T2DM.

\begin{tabular}{|c|c|c|c|}
\hline Author and Year & $\begin{array}{c}\text { Number of } \\
\text { Patients }\end{array}$ & $\begin{array}{l}\text { Method of Mg } \\
\text { Determination }\end{array}$ & Main Results \\
\hline van Dijk et al. (2019) [60] & 5568 & $\begin{array}{l}\text { Serum } \\
\text { (xylidyl blue test) }\end{array}$ & $\begin{array}{l}(-) \text { correlation of } \mathrm{Mg} \text { (measured by nuclear magnetic } \\
\text { resonance spectroscopy and colorimetric assays) and TG } \\
(\mathrm{r}=-0.184, p=0.002 \text { and } \mathrm{r}=-0.194, p=0.001 \\
\text { respectively) }\end{array}$ \\
\hline Rusu et al. (2013) [61] & 154 & $\begin{array}{c}\text { Serum } \\
\text { (automated multianalyzer) }\end{array}$ & $\begin{array}{c}\text { T2DM + peripheral arterial disease: } \downarrow \mathrm{Mg}(p<0.01), \downarrow \\
\text { HDL-C, } \uparrow \mathrm{TG}, \uparrow \mathrm{TC}\end{array}$ \\
\hline Spiga et al. (2019) [62] & 589 & $\begin{array}{l}\text { Serum } \\
\text { (colorimetric assay) }\end{array}$ & $\begin{array}{c}\downarrow \mathrm{Mg}, \downarrow \text { HDL-C, } \uparrow \mathrm{TG} \text { in normal glucose tolerance } \rightarrow \\
\text { impaired fasting glucose } \rightarrow \text { T2DM }(p<0.02, p<0.01 \text { and } \\
p<0.001, \text { respectively) } \\
(+) \text { correlations: Mg and TC }(\mathrm{r}=0.154, p<0.001), \text { HDL-C } \\
(\mathrm{r}=0.113, p<0.01), \mathrm{LDL}-\mathrm{C}(\mathrm{r}=0.170, p<0.001) \\
\uparrow \mathrm{Mg}: \downarrow \text { risk of T2DM (OR }=0.765,95 \% \text { CI } 0.629-0.932, \\
p<0.01)\end{array}$ \\
\hline Esmeralda et al. (2021) [63] & 62 & $\begin{array}{l}\text { Serum and urine analysis } \\
\text { (methods unspecified) }\end{array}$ & $\begin{array}{c}\text { T2DM: } \uparrow \mathrm{TG}(p=0.004), \uparrow \text { fractional excretion of } \mathrm{Mg} \\
(p=0.01), \downarrow \text { serum } \mathrm{Mg}(p=0.001) \text { versus controls }\end{array}$ \\
\hline Gopal et al. (2019) [64] & 90 & $\begin{array}{l}\text { Serum } \\
\text { (calmagite colorimetric } \\
\text { test) }\end{array}$ & $\begin{array}{c}\text { Mg concentrations predict proliferative retinopathy } \\
\text { development in T2DM (optimum cut-off } 1.7 \mathrm{mg} / \mathrm{dL}, \\
\text { sensitivity } 92.86 \% \text {, specificity } 77.14 \% \text {, AUC } 0.837, \text { SEM 0.06, } \\
95 \% \text { CI } 0.70-0.92) \\
\mathrm{Mg} \downarrow: \text { no retinopathy } \rightarrow \text { non-proliferative retinopathy } \rightarrow \\
\text { proliferative retinopathy }(p<0.01) \\
\text { proliferative retinopathy: } \uparrow \text { HDL-C }(p<0.05) \text {, similar TC, } \\
\text { TG, LDL-C, VLDL }\end{array}$ \\
\hline Hruby et al. (2017) [65] & 202,743 & Unspecified & $\begin{array}{c}\text { 15\% T2DM-risk } \downarrow \text { in individuals with } \uparrow \text { dietary intake } \\
\text { of } \mathrm{Mg} \\
\uparrow \text { Hypercholesterolemia in the } 5 \text { th }(12.7 \% \text { for } \\
\text { 427-498 mg/day) versus } 1 \text { st first }(8.7 \% \text { for } 242-275 \\
\text { mg / day) quartile of } \mathrm{Mg} \text { intake }\end{array}$ \\
\hline Anetor et al. (2002) [66] & 60 & $\begin{array}{c}\text { Serum } \\
\text { (spectrophotometry) }\end{array}$ & $(+)$ association of $\mathrm{Mg}$ and $\mathrm{TC}(\mathrm{r}=0.6 ; p<0.001)$ \\
\hline Corica et al. (2006) [67] & 290 & $\begin{array}{c}\text { Serum } \\
\text { (ion selective analyzer) }\end{array}$ & $\downarrow \mathrm{Mg}: \downarrow$ HDL-C $(p<0.001)$ and $\uparrow \mathrm{TG}(p<0.001)$ \\
\hline Romero and Moran (2000) [68] & 390 & $\begin{array}{c}\text { Serum } \\
\text { (chemical autoanalyzer) }\end{array}$ & $\begin{array}{c}\downarrow \mathrm{Mg} \text { associated with } \downarrow \text { HDL-C ( } p=0.01 \text { in T2DM; } p=0.05 \\
\text { in IFG; } p=0.03 \text { for controls) }\end{array}$ \\
\hline Yu et al. (2018) [69] & 8163 & $\begin{array}{l}\text { Serum } \\
\text { (xylidyl blue test) }\end{array}$ & $\begin{array}{c}\uparrow \text { serum lipids, except for HDL-C, across progressive } \mathrm{Mg} \\
\text { concentrations (from } \downarrow \mathrm{Mg} \text { of } \leq 0.65 \mathrm{mmol} / \mathrm{L} \text {, normal } \\
0.65-0.95 \mathrm{mmol} / \mathrm{L}, \uparrow \text { levels } \geq 0.95 \mathrm{mmol} / \mathrm{L})(p<0.05) \\
\uparrow \mathrm{TG}, \mathrm{TC}, \mathrm{HDL}-\mathrm{C} \text { and } \mathrm{LDL}-\mathrm{C}(\mathrm{Mg} \geq 0.95 \mathrm{mmol} / \mathrm{L} \text { versus } \downarrow \\
\mathrm{Mg}, p<0.05)\end{array}$ \\
\hline Kurstjens et al. (2016) [70] & 395 & $\begin{array}{l}\text { Serum } \\
\text { (spectrophotometry) }\end{array}$ & $\begin{array}{l}(-) \text { negative correlation of } \mathrm{Mg} \text { and } \mathrm{TG}(\mathrm{r}=-0.273 \\
\quad p<0.001) \\
(+) \text { positive correlation of } \mathrm{Mg} \text { and HDL-C }(\mathrm{r}=0.156 \\
p=0.002)\end{array}$ \\
\hline
\end{tabular}

$\mathrm{Mg}$, magnesium. MetS, metabolic syndrome. T2DM, type 2 diabetes mellitus. HTN, hypertension. hypoMg, hypomagnesemia. OR, odds

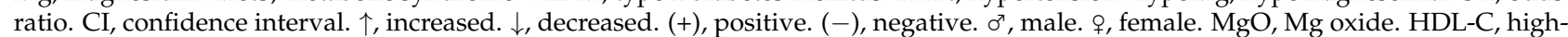
density lipoprotein cholesterol. LDL-C, low-density lipoprotein cholesterol. TC, total cholesterol. TG, triglycerides. VLDL, very low-density lipoprotein cholesterol. apoA1, apolipoprotein A1. oxLDL, oxidized LDL. RDV, recommended dietary value. $\Delta$, variation. $\mathrm{MgCl} 2, \mathrm{Mg}$ chloride. mg, milligrams. g, grams. mL, milliliter. K, potassium. MONW, metabolically obese normal-weight. NW, normal weight. 


\subsubsection{Hypomagnesemia}

Rasheed et al. (2012) compared laboratory variables in 219 T2DM patients and 100 healthy controls, depicting a higher prevalence of hypomagnesemia, higher TG and LDL-C and lower HDL-C concentrations in the study group [71]. Srinivasan el al. (2012) also unmasked that, in T2DM, hypomagnesemia not normomagnesemia positively correlated with TG concentrations $(p<0.05)$ [72]. Pokharel et al. (2017) researched the association of serum $\mathrm{Mg}$ and different cardiovascular risk factors in 150 Nepalese T2DM subjects versus 50 controls. Hypomagnesemia was discovered in 50\% of T2DM individuals versus $0 \%$ in the healthy counterparts. An inverse correlation between serum $\mathrm{Mg}$ and TC $(\mathrm{r}=-0.219 ; p<0.01)$ and LDL-C $(\mathrm{r}=-0.168 ; p<0.05)$ was detected. $\mathrm{Mg}$ concentrations were similar $(p>0.05)$ between overweight, hypertensive, and dyslipidemic T2DM patients and the control group. The authors concluded that based on their study a nutritional supplement of $\mathrm{Mg}$ was warranted for the prevention and minimization of chronic T2DM systemic complications such as insulin resistance and dyslipidemia [73]. Hyassat et al. (2014) analyzed 1105 overweight/obese subjects diagnosed with T2DM and detected a prevalence of hypomagnesemia of 19\% (95\% CI: 16.8-21.4\%) in the study group. Patients who were dyslipidemic or were prescribed statins were more likely to associate low serum $\mathrm{Mg}$ concentrations ( $p=0.022$ and $p<0.001$, respectively). Low serum Mg levels remained associated with the administration of statins in the multivariate logistic regression as well $(\mathrm{OR}=1.56,95 \%$ CI: 1.1-2.2) [74]. Waanders et al. (2019) investigated the crosstalk between T2DM and hypomagnesemia in 929 Dutch individuals, demonstrating that Mg concentrations correlated with TC $(\mathrm{r}=0.142, p<0.001)$, TC/HDL-C ratio $(\mathrm{r}=0.114, p<0.001)$, and LDL-C $(\mathrm{r}=0.166, p<0.001)$, but not with HDL-C $(\mathrm{r}=-0.003, p=0.923)$ or TG $(\mathrm{r}=0.002$, $p=0.941)$. The results of the stepwise multivariable regression revealed a significant association of serum Mg with LDL-C ( $\beta=0.141, p=0.001)$ [75]. In Huang et al. (2012)'s cross-sectional observational study on 210 T2DM subjects aged $>65$ years, the appraisal of nutritional habits unmasked an insufficient $\mathrm{Mg}$ intake in $>88 \%$ and hypomagnesemia in $37 \%$ of the individuals. Mg intake was positively correlated with HDL-C ( $\mathrm{r}=0.192$; $p=0.005$ ) [76]. Corsonello et al. (2000) conducted a study on 90 T2DM patients (30 patients without albuminuria, 30 with microalbuminuria and 30 with proteinuria) and observed a decrease in serum $\mathrm{Mg}$ and an increase in TG as the urinary protein loss increased $(p<0.001)$. However, the presence of hypomagnesemia was not associated with hypercholesterolemia, despite higher TC being detected in the patients with hypomagnesemia [77]. Shardha et al. (2014) investigated the relationship between serum Mg levels and serum lipids in T2DM individuals suffering from hypokalemia. TG $(234.50 \mathrm{mg} / \mathrm{dl}$ versus $169 \mathrm{mg} / \mathrm{dL} ; p=0.001)$ and LDL-C $(123 \mathrm{mg} / \mathrm{dL}$ versus $105 \mathrm{mg} / \mathrm{dL} ; p<0.001)$ were higher and HDL-C (39 mg/dL versus $46 \mathrm{mg} / \mathrm{dL} ; p<0.001$ ) was lower in hypokalemic T2DM individuals who associated hypomagnesemia [78].

The most relevant information of this subsection are summarized in Table 4. 
Table 4. Interplay of hypomagnesemia and T2DM.

\begin{tabular}{|c|c|c|c|}
\hline Author and Year & $\begin{array}{c}\text { Number of } \\
\text { Patients }\end{array}$ & $\begin{array}{l}\text { Method of } \mathrm{Mg} \\
\text { Determination }\end{array}$ & Main Results \\
\hline Rasheed et al. (2012) [71] & 319 & $\begin{array}{c}\text { Serum } \\
\text { (spectrophotometry) }\end{array}$ & $\begin{array}{l}\uparrow \text { prevalence of hypoMg in T2DM } \\
\text { hypoMg: } \uparrow \mathrm{TG}, \uparrow \text { LDL-C, } \downarrow \text { HDL-C }\end{array}$ \\
\hline Srinivasan el al. (2012) [72] & 30 & $\begin{array}{c}\text { Serum } \\
\text { (calmagite colorimetric } \\
\text { test) }\end{array}$ & association of hypoMg and TG $(p<0.05)$ \\
\hline Pokharel et al. (2017) [73] & 300 & $\begin{array}{c}\text { Serum } \\
\text { (xylidyl blue test) }\end{array}$ & $\begin{array}{c}\uparrow \text { prevalence of hypoMg in T2DM: } 50 \% \\
(-) \text { correlation of } \mathrm{Mg} \text { and TC }(\mathrm{r}=-0.219 ; \\
p<0.01), \text { LDL-C }(\mathrm{r}=-0.168 ; p<0.05)\end{array}$ \\
\hline Hyassat et al. (2014) [74] & 1105 & $\begin{array}{c}\text { Serum } \\
\text { (colorimetric assay) }\end{array}$ & $\begin{array}{c}\uparrow \text { prevalence of hypoMg in overweight/obese } \\
\text { T2DM: } 19 \% \\
\text { dyslipidemia, statin use associated with hypoMg } \\
(p=0.022 \text { and } p<0.001 \text {, respectively) } \\
\text { hypoMg-statin use association (OR }=1.56,95 \% \\
\text { CI: } 1.1-2.2)\end{array}$ \\
\hline Waanders et al. (202p) [75] & 929 & $\begin{array}{c}\text { Serum } \\
\text { (colorimetric assay) }\end{array}$ & $\begin{array}{l}\text { (+) associations of } \mathrm{Mg} \text { and } \mathrm{TC}(\mathrm{r}=0.142, \\
p<0.001), \mathrm{TC} / \mathrm{HDL}-\mathrm{C} \text { ratio }(\mathrm{r}=0.114, p<0.001), \\
\text { LDL-C }(\mathrm{r}=0.166, p<0.001) \\
\text { stepwise multivariable regression: } \mathrm{Mg} \text { associated } \\
\text { with LDL-C }(\beta=0.141, p=0.001)\end{array}$ \\
\hline Huang et al. (2012) [76] & 210 & $\begin{array}{c}\text { Serum } \\
\text { (methylthymol blue method) }\end{array}$ & $\begin{array}{c}\text { T2DM, }>65 \text { years: insufficient } \mathrm{Mg} \text { intake }(>88 \%), \\
\text { hypoMg }(37 \%) \\
(+) \text { association of } \mathrm{Mg} \text { intake and HDL-C } \\
(\mathrm{r}=0.192 ; p=0.005)\end{array}$ \\
\hline Corsonello et al. (2000) [77] & 110 & $\begin{array}{c}\text { Serum } \\
\text { (ion selective analyzer) }\end{array}$ & $\begin{array}{c}\downarrow \mathrm{Mg}, \uparrow \mathrm{TG} \text { with the } \uparrow \text { urinary protein loss } \\
\left(\begin{array}{c}(p<0.001) \\
\text { hypoMg: } \uparrow \mathrm{TC}\end{array}\right.\end{array}$ \\
\hline Shardha et al. (2014) [78] & 358 & $\begin{array}{c}\text { Serum } \\
\text { (method unspecified) }\end{array}$ & $\begin{array}{c}\uparrow \mathrm{TG}(p=0.001), \uparrow \mathrm{LDL}-\mathrm{C}(p<0.001), \downarrow \text { HDL-C } \\
(p<0.001) \text { in T2DM }+ \text { hypoK }+ \text { hypoMg }\end{array}$ \\
\hline
\end{tabular}

$\mathrm{Mg}$, magnesium. MetS, metabolic syndrome. T2DM, type 2 diabetes mellitus. HTN, hypertension. hypoMg, hypomagnesemia. OR, odds ratio. CI, confidence interval. $\uparrow$, increased. $\downarrow$, decreased. (+), positive. (-), negative. $\diamond^{7}$, male. $q$, female. MgO, Mg oxide. HDL-C, high-density lipoprotein cholesterol. LDL-C, low-density lipoprotein cholesterol. TC, total cholesterol. TG, triglycerides. VLDL, very low-density lipoprotein cholesterol. apoA1, apolipoprotein A1. oxLDL, oxidized LDL. RDV, recommended dietary value. $\Delta$, variation. $\mathrm{MgCl}_{2}, \mathrm{Mg}$ chloride. mg, milligrams. g, grams. $\mathrm{mL}$, milliliter. $\mathrm{K}$, potassium. MONW, metabolically obese normal-weight. NW, normal weight. hypoK, hypokalemia.

\subsubsection{Magnesium Supplementation in RCTs and Interventional Studies}

Song et al. (2006)'s meta-analysis of RCTs unmasked that supplementation with Mg elevated HDL-C in T2DM subjects (+0.08 mmol/L, 95\% CI 0.03-0.14, $p=0.36$ for heterogeneity), but failed to produce effects on TG, TC or LDL-C [79]. Hamedifard et al. (2020) conducted a 12-week RCT in which they compared the administration of $250 \mathrm{mg}$ $\mathrm{Mg}$ oxide plus $150 \mathrm{mg}$ zinc sulfate versus placebo in $60 \mathrm{~T} 2 \mathrm{DM}$ subjects suffering from coronary heart disease. The intervention did not yield any significant changes in TC, TC/HDL-C ratio, LDL-C, VLDL or TG, however it resulted in a notable increase in HDL$\mathrm{C}(\beta=2.09 \mathrm{mg} / \mathrm{dL}, 95 \% \mathrm{CI}, 0.05,4.13 ; p=0.04)$ versus placebo [80]. Al-Daghri et al. (2014) supplemented a cohort of 126 Saudi T2DM subjects with vitamin D and detected a significant positive correlation between serum Mg and TG $(r=0.32, p=0.04)$ in males. In females, there was a positive correlation $(r=0.36, p=0.006)$ between HDL-C and the variation in $\mathrm{Mg}$ concentrations following 6 months of vitamin D supplementation [81]. Rashvand et al. (2019) explored the impact of $500 \mathrm{mg} \mathrm{Mg}$ oxide versus $1000 \mathrm{mg}$ choline bitartrate versus $\mathrm{Mg}+$ choline co-supplementation versus placebo on the lipid profile of 96 T2DM subjects in a 2-month RCT. Mg supplementation alone raised serum $\mathrm{Mg}$ concentrations $(p=0.02)$, but failed to alter the values of TG $(p=0.24)$, TC $(p=0.48)$, LDL-C $(p=0.89)$, HDL-C $(p=0.09)$, or LDL-C/HDL-C $(p=0.62)$. Choline supplementation alone did not have any impact on the lipid profile as well. However, the $\mathrm{Mg}+\mathrm{choline}$ intervention elevated $\mathrm{Mg}$ levels ( $p<0.001$ versus $p=0.02$ for $\mathrm{Mg}$ supplementation alone), decreased TG $(p=0.04)$, increased HDL-C $(p=0.01)$, but did not alter TC $(p=0.92)$, LDL-C 
$(p=0.44)$ or LDL-C/HDL-C $(p=0.08)$ [82]. Dietary interventions, such as honey enriched with $\mathrm{Mg}$, cinnamon, and chromium, was also able to decrease LDL-C $(-0.29 \mathrm{mmol} / \mathrm{L}$; $95 \% \mathrm{CI}-0.57$ to $-0.23 ; p=0.039)$ and TC $(-0.37 \mathrm{mmol} / \mathrm{L} ; 95 \% \mathrm{CI}-0.073$ to -0.008 ; $p=0.046$ ) values versus standard honey in an RCT involving subjects diagnosed with T2DM, yet TG and HDL-C values remained unaltered [83]. In their recent meta-analysis of 4 RCTs, Dehbalaei et al. (2021) analyzed the effects of combined $250 \mathrm{mg} /$ day of $\mathrm{Mg}$ and $400 \mathrm{IU} /$ day of vitamin E supplementation for 6-12 weeks on the lipid profile in 119 participants suffering from T2DM-induced foot ulcers, gestational diabetes or polycystic ovary syndrome versus 118 controls. The intervention yielded a reduction in TC (WMD: $-15.89 \mathrm{mg} / \mathrm{dL}, 95 \%$ CI: 24.39, 7.39, $p<0.001$ ), LDL-C (WMD: $-11.37 \mathrm{mg} / \mathrm{dL}, 95 \% \mathrm{CI}$ : 19.32, 3.41, $p=0.005$ ), and TG (WMD: $-26.97 \mathrm{mg} / \mathrm{dL}, 95 \%$ CI: 46.03, 7.90, $p=0.006$ ), but did not influence HDL-C (WMD: $1.59 \mathrm{mg} / \mathrm{dL}, 95 \%$ CI: 0.17, 3.35, $p=0.076$ ) [84]. According to Yokota et al. (2004), a 30-day supplementation with $300 \mathrm{mg} /$ day of $\mathrm{Mg}$ did not modify TC, HDL-C, or TG in T2DM subjects [85]. Djurhuus et al. (2001) monitored the effects of 24 weeks of oral supplementation with $\mathrm{Mg}$ in patients with type 1 diabetes and hypomagnesemia. Although TG levels increased in the first week, at 24 weeks the authors noted a reduction in LDL-C, TC, and apoB. Intravenous administration of $\mathrm{Mg}$ resulted in a more pronounced decrease of the same parameters [86]. Ham and Shon (2020) conducted an RCT in which they evaluated the 8-week administration of deep-sea water enriched with $\mathrm{Mg}$ versus placebo in 74 individuals with prediabetes. Following the intervention, the authors recorded a significant reduction in LDL-C $(p=0.003)$ and TC $(p=0.006)$, but HDL-C and TG remained unchanged [87]. However, in their RCT, Cosaro et al. (2014) detected no benefits of Mg supplementation in terms of TC, LDL-C, or TG reduction and HDL-C elevation in a small study group of 7 males aged 23-33 years who had a positive family history for T2DM/MetS versus 7 healthy controls [88]. Asemi et al. (2015) conducted an RCT to investigate the effects of Mg supplementation in females suffering from gestational diabetes and concluded that the placebo group had higher values of TC $(p=0.01)$, VLDL $(p=0.005)$, and TG $(p=0.005)$ at the end of the intervention versus the baseline. In both the placebo and the Mg-deficient women's group, HDL-C, LDL-C and TC/HDL-C ratio did not change significantly throughout the RCT [89]. In NavarreteCortes et al. (2014)'s RCT, a 3-month administration of $360 \mathrm{mg} \mathrm{Mg}$ daily failed to lead to any changes in TC, TG, LDL-C, or HDL-C in T2DM subjects with normomagnesemia versus placebo [90]. Another RCT, conducted by Guerrero-Romero et al. (2015), explored the benefits of $30 \mathrm{~mL}$ of $\mathrm{MgCl}_{2} 5 \%$ solution (equivalent to $382 \mathrm{mg} \mathrm{Mg}$ ) versus placebo in 59 individuals diagnosed with hypomagnesemia and prediabetes versus controls. At the end of the intervention which lasted for 4 months, the study group displayed an elevation in HDL-C $(+4.7 \pm 10.5 \mathrm{mg} / \mathrm{dL}$ versus $-3.9 \pm 11.3 \mathrm{mg} / \mathrm{dL}, p=0.04)$ and a reduction in TG $(-57.1 \pm 80.7 \mathrm{mg} / \mathrm{dL}$ versus $-30.9 \pm 87.7, p=0.009)$ as compared to placebo [91]. In the RCT performed by Solati et al. (2014), 25 T2DM patients who received $300 \mathrm{mg}$ / day of Mg sulfate for a period of 3 months were compared to $22 \mathrm{~T} 2 \mathrm{DM}$ patients who received placebo. Following $\mathrm{Mg}$ prescription, the intervention group displayed lower LDL-C $(93.63 \pm 24.58 \mathrm{mg} / \mathrm{dL}$ versus $120.4 \pm 34.86 \mathrm{mg} / \mathrm{dL} ; p<0.01)$ and non-HDL-C $(125.30 \pm 23.19 \mathrm{mg} / \mathrm{dL}$ versus $152.16 \pm 37.05 \mathrm{mg} / \mathrm{dL} ; p<0.001)$ levels at the end of the RCT, but TG, TC, and HDL-C concentrations were similar to the placebo group [92]. De Valk et al. (1998) supplemented 34 patients with controlled T2DM with Mg aspartate for 3 months, but failed to detect significant changes in serum lipids in the intervention versus control group [93]. Similarly, the 90-day administration of $600 \mathrm{mg} /$ day of $\mathrm{Mg}$ in 56 T2DM patients did not alter TC, HDL-C, or LDL-C [94]. Talari et al. executed an RCT in which 54 Iranian T2DM patients on hemodialysis were prescribed $250 \mathrm{mg} /$ day of $\mathrm{Mg}$ oxide for 24 weeks. There was a significant decrease in TC $(p=0.02)$ and LDL-C ( $p=0.01)$ in the group receiving Mg [95]. In another 12-week RCT, Afzali et al. (2019) studied the effects of $250 \mathrm{mg}$ /day Mg oxide + $400 \mathrm{IU}$ vitamin $\mathrm{E}$ in 57 patients with diabetic foot. The intervention group exhibited a decrease in TG $(p=0.04)$ and LDL-C $(p=0.03)$, as well as an increase in HDL-C ( $p=0.01)$ [96]. In a cross-sectional study, Brandao-Lima 
et al. (2019) researched the impact of zinc, potassium, calcium, and $\mathrm{Mg}$ administration at different concentrations in 95 T2DM patients. Higher levels of TG $(p=0.01)$, TC $(p=0.097)$, LDL-C $(p=0.0867)$, and HDL-C ( $p=0.0247)$ were observed in the group that received the aforementioned elements in lower concentrations [97]. In a 6-week RCT performed by Karamali M. et al. (2018), 60 patients with gestational diabetes mellitus were given either Mg-zinc-calcium-vitamin D co-supplements or placebo ( $\mathrm{n}=30$ each group). The combined supplementation significantly decreased TG $(-0.27 \pm 0.89$ versus $+0.36 \pm 0.39 \mathrm{mmol} / \mathrm{L}$, $p=0.001)$ and VLDL $(-0.13 \pm 0.40$ versus $+0.16 \pm 0.18 \mathrm{mmol} / \mathrm{L}, p=0.001)$ as compared to placebo [98]. Sedeghian et al. (2020) conducted a 12-week RCT to assess the effects of Mg sulfate supplementation in 80 patients with early diabetic nephropathy, but did not detect significant changes in serum Mg or TC, LDL-C, HDL-C, TC/HDL-C, or TG [99].

\subsection{Crosstalk of Magnesium, Serum Lipids and Cardiovascular Disorders}

A total of 16 studies assessed the crosstalk of $\mathrm{Mg}$, serum lipids, and cardiovascular disorders, focusing on the relationship of serum $\mathrm{Mg}$ with the lipid profile in atherosclerosis, angina pectoris, acute myocardial infarction, coronary heart disease, coronary artery calcifications, as well as hypertension $(n=7)$.

\subsubsection{Atherosclerosis, Angina Pectoris and Acute Myocardial Infarction}

The prevalence of hypercholesterolemia was equally balanced among serum Mg concentrations in 414 patients younger than 50 years old who were subjected to drug-eluding stent implantation following an acute coronary syndrome [100]. Qazmooz et al. (2020) analyzed the crosstalk between several trace elements (including $\mathrm{Mg}$ ) and subjects with atherosclerosis versus unstable angina versus healthy controls. Patients with atherosclerosis had higher $\mathrm{Mg}$ levels versus controls and unstable angina patients. In the subjects diagnosed with atherosclerosis or unstable angina, elevated TC, Castelli index 1 (zTCzHDL-C) and lower HDL-C levels were recorded as compared to controls. In addition, there were significant differences in terms of LDL-C, TG, atherogenic index of plasma (zTG-zHDL-C), Castelli index 2 (zLDL-C-zHDL-C) between study groups. TG and the atherogenic index of plasma (zTG-zHDL-C) increased as follows: controls $\rightarrow$ atherosclerosis $\rightarrow$ unstable angina. LDL-C and the Castelli index 2 (zLDL-C-zHDL-C) increased as follows: controls $\rightarrow$ unstable angina $\rightarrow$ atherosclerosis. Based on the results of the multiple regression analysis, $\mathrm{Mg}$ was one of the explanatory variables accounting for the variance in the atherogenic index of plasma $(\beta=-0.205, \mathrm{t}=-3.036, p=0.003)$, Castelli index 1 $(\beta=-0.179, \mathrm{t}=-2.633, p=0.009)$, Castelli index $2(\beta=-0.143, \mathrm{t}=-1.983, p=0.049)$ and HDL-C ( $\beta=0.157, t=2.106, p=0.037)$ [101]. Brown et al. (1958) had also sought to examine the interplay of $\mathrm{Mg}$, serum lipids and myocardial infarction in 186 adults who attended the Cardiovascular Health Center at Albany Medical College annually, but did not discover statistically significant associations of $\mathrm{Mg}$ and serum cholesterol, total lipids or alpha/beta lipoproteins [102]. The findings of Mahalle el al. (2012) regarding the crosstalk of Mg and serum lipids in 300 patients with known cardiovascular disease also delineate that TC, LDL-C, VLDL and TG are higher and HDL-C is lower in subjects with low serum Mg [103].

\subsubsection{Coronary Heart Disease}

In the ARIC study, Liao et al. (1998) looked into the correlation between serum $\mathrm{Mg}$ levels and risk factors for coronary heart disease, including TC, TG, and HDL-C. The nearly 13,000 patients enrolled exhibited an increase in TC and HDL-C, as well as a decrease in LDL-C, with increasing serum Mg values [104]. Farshidi et al. (2020) conducted a 6-month RCT in which they prescribed $300 \mathrm{mg} /$ day of $\mathrm{Mg}$ sulfate to 32 patients with coronary heart disease versus 32 subjects who received placebo. At the 3-month evaluation, the authors demonstrated a decrease in oxLDL and TC/HDL-C ratio versus placebo. Patients with one atherosclerotic vessel benefited from a reduction in LDL-C, whereas patients with more affected vessels registered an elevation in HDL-C. At 6 months, there were significant alterations of oxLDL, LDL-C, and HDL-C in subjects with one interested vessel, as well as 
LDL-C alterations in patients with at least two atherosclerotic vessels. Notable changes in the concentrations of oxLDL receptors was seen. During the 3 months between evaluations, oxLDL decreased in subjects with only one vessel interested by atherosclerosis [105]. Petersen et al. (1977) examined a cohort of seventy three men and women and evaluated the relationship between serum and erythrocyte $\mathrm{Mg}$ and several indicators of coronary heart disease, detecting a significant inverse correlation of serum $\mathrm{Mg}$ and systolic blood pressure $(\mathrm{r}=-0.31, p<0.01)$, and a significant positive correlation of erythrocyte $\mathrm{Mg}$ and TC $(\mathrm{r}=0.25, p<0.05)[106]$.

\subsubsection{Coronary Artery Calcifications}

Posadas-Sanchez et al. (2016) sought to examine the association between serum $\mathrm{Mg}$ levels and coronary artery calcification. The authors included a total of one thousand two hundred and seventy six subjects in their study. Blood serum values of $\mathrm{Mg}$ were compared to the values of LDL-C, HDL-C, TG, TC, apolipoproteins A and B, and using regression models, correlation studies were performed. After dividing the study participants according to their serum $\mathrm{Mg}$ quartiles, four groups were formed. None of the lipid profile components showed significant differences based on $\mathrm{Mg}$ quartiles, with the mean values of LDL-C, HDL-C, TG, apolipoprotein A and B being similar patients with hypomagnesemia and patients with normal serum $\mathrm{Mg}$ [107]. Lee et al. (2015) examined the relationship between low serum $\mathrm{Mg}$ and coronary artery calcification in a cross-sectional study which included 34,553 subjects who underwent coronary multi-detector computer tomography and serum $\mathrm{Mg}$ measurement as part of a health program in Korea. After differentiating the cohort based on their serum $\mathrm{Mg}$ levels, and dividing them into three groups (low < $1.9 \mathrm{mg} / \mathrm{dL}$, normal 1.9-2.3 mg/dL, high > $2.3 \mathrm{mg} / \mathrm{dL}$ ), the mean values of TC, LDL-C and HDL-C were compared, but no differences in serum lipids were seen based on the Mg subgroups [108].

\subsubsection{Hypertension}

Zemel et al. (1990) explored the benefits of Mg supplementation during a 3-month RCT, but hypertensive patients displayed no significant changes in serum lipids [109]. On the other hand, Motoyama et al. (1989)'s prescription of $600 \mathrm{mg}$ of $\mathrm{Mg}$ oxide for 4 weeks to 21 hypertensive men resulted in significant decreases in TG and free fatty acids [110]. The 4-month supplementation with $2.5 \mathrm{MgCl}_{2}$ (450 mg Mg) employed by Guerrero-Romero and Rodriguez-Moran (2008) in their RCT led to significant improvements in HDL-C levels versus placebo in subjects diagnosed with hypertension [111]. In the prospective, 3-year observational Esfandiari et al. (2017)'s study tracking the effects of the adherence to the DASH diet, it was found that a higher questionnaire-assessed DASH score was associated with a higher Mg consumption and lower TC $(p<0.05)$ [112]. Cunha et al. (2016) performed an RCT to investigate oral Mg supplementation and its effects on the improvement of endothelial function and subclinical atherosclerosis in thiazide-treated hypertensive women. There was a significant difference in HDL-C and LDL-C between the placebo group $(n=18)$ and the Mg supplemented group $(n=17)$ at the start of the trial compared to the mean values determined at the end of the clinical trial, but $\mathrm{Mg}$ administration failed to alter the HDL-C $(p=0.720)$ or LDL-C $(p=0.058)$ concentrations [113]. As a strategy to combat hypertension, Karppanen et al. (1984) examined the benefits of $\mathrm{KCl}-\mathrm{NaCl}-\mathrm{MgCl}_{2}$ (low in sodium) salts as a replacement for the common table salt $(\mathrm{NaCl})$ used for food preparation. Multiple measurements were made before, after, and during the time that the patients received the salt mixture, including TC and TG. Although serum Mg significantly increased, no statistically significant changes in TC or TG were seen [114]. Delva et al. (1998) discovered that low intra-lymphocytic Mg levels correlated with an increase in TG, regardless of the patients' hypertensive or normotensive status [115].

The most relevant information of this subsection are summarized in Table 5. 
Table 5. Interplay of magnesium and serum lipids in cardiovascular disorders.

\begin{tabular}{|c|c|c|c|c|}
\hline Author and Year & Condition & $\begin{array}{l}\text { Number of } \\
\text { Patients }\end{array}$ & $\begin{array}{l}\text { Method of Mg } \\
\text { Determination }\end{array}$ & Main Results \\
\hline $\begin{array}{l}\text { Qazmooz et al. (2020) } \\
\text { [101] }\end{array}$ & $\begin{array}{l}\text { atherosclerosis versus } \\
\text { unstable angina }\end{array}$ & 178 & $\begin{array}{l}\text { Serum } \\
\text { (spectrophotometry) }\end{array}$ & $\begin{array}{c}\uparrow \mathrm{Mg} \text { in atherosclerosis versus controls } \\
\text { and unstable angina } \\
\mathrm{Mg} \text { explained the variance in AIP } \\
(\beta=-0.205, \mathrm{t}=-3.036, p=0.003), \\
\text { Castelli index } 1(\beta=-0.179, \mathrm{t}=-2.633, \\
p=0.009), \text { Castelli index } 2(\beta=-0.143, \\
\mathrm{t}=-1.983, p=0.049), \text { HDL-C }(\beta=0.157, \\
\mathrm{t}=2.106, p=0.037)\end{array}$ \\
\hline Brown et al. (1958) [102] & myocardial infarction & 1225 & $\begin{array}{c}\text { Serum } \\
\text { (spectrophotometry) }\end{array}$ & $\begin{array}{c}\text { Mg not associated with serum } \\
\text { cholesterol, total lipids, } \alpha / \beta \text { lipoproteins }\end{array}$ \\
\hline Mahalle el al. (2012) [103] & cardiovascular disease & 300 & $\begin{array}{c}\text { Serum } \\
\text { (xylidyl blue test) }\end{array}$ & $\begin{array}{c}\downarrow \mathrm{Mg}: \uparrow \mathrm{TC}, \uparrow \mathrm{LDL}-\mathrm{C}, \uparrow \mathrm{VLDL}, \uparrow \mathrm{TG} \text { and } \\
\downarrow \\
\downarrow \text { HDL-C }\end{array}$ \\
\hline Liao et al. (1998) [104] & $\mathrm{CHD}$ & 13,922 & $\begin{array}{c}\text { Serum } \\
\text { (calmagite colorimetric } \\
\text { test) }\end{array}$ & $\uparrow \mathrm{Mg}=\uparrow \mathrm{TC}, \uparrow \mathrm{HDL}-\mathrm{C}, \downarrow$ LDL-C \\
\hline Petersen et al. (1977) [106] & CHD & 73 & $\begin{array}{l}\text { Serum, erythrocytes } \\
\text { (spectrophotometry) }\end{array}$ & $\begin{array}{l}(+) \text { correlation of erythrocyte } \mathrm{Mg} \text { and TC } \\
(\mathrm{r}=0.25, p<0.05)\end{array}$ \\
\hline $\begin{array}{l}\text { Posadas-Sanchez et al. } \\
\text { (2016) [107] }\end{array}$ & CAC & 1276 & $\begin{array}{l}\text { Serum } \\
\text { (xylidyl blue test) }\end{array}$ & $\begin{array}{l}\text { hypoMg and normoMg: similar LDL-C, } \\
\text { HDL-C, TG, apolipoprotein A/B }\end{array}$ \\
\hline Lee et al. (2015) [108] & CAC & 34,553 & $\begin{array}{l}\text { Serum } \\
\text { (colorimetric assay) }\end{array}$ & $\begin{array}{c}\text { no TC, LDL-C, HDL-C difference across } \\
\text { Mg subgroups: } \downarrow<1.9 \mathrm{mg} / \mathrm{dL} \text {, normal } \\
1.9-2.3 \mathrm{mg} / \mathrm{dL}, \uparrow>2.3 \mathrm{mg} / \mathrm{dL}\end{array}$ \\
\hline $\begin{array}{l}\text { Esfandiari et al. (2017) } \\
\text { [112] }\end{array}$ & $\mathrm{HTN}$ & 927 & Unspecified & $\begin{array}{c}\uparrow \text { questionnaire-assessed DASH score }=\uparrow \\
\text { Mg and } \downarrow \text { TC }(p<0.05)\end{array}$ \\
\hline $\begin{array}{l}\text { Karppanen et al. (1984) } \\
\text { [114] }\end{array}$ & $\mathrm{HTN}$ & 126 & $\begin{array}{l}\text { Serum } \\
\text { (method unspecified) }\end{array}$ & $\begin{array}{c}\mathrm{KCl}-\mathrm{NaCl}-\mathrm{MgCl}_{2} \text { salts versus common } \\
\text { table salt }(\mathrm{NaCl}) \uparrow \mathrm{Mg} \text { but no effect on } \\
\mathrm{TC}, \mathrm{TG}\end{array}$ \\
\hline Delva et al. (1998) [115] & $\mathrm{HTN}$ & 52 & $\begin{array}{l}\text { Intralymphocyte } \\
\text { (fluorimetric test) }\end{array}$ & $\begin{array}{c}\downarrow \text { intra-lymphocytic Mg associated with } \\
\uparrow \mathrm{TG}\end{array}$ \\
\hline
\end{tabular}

$\mathrm{Mg}$, magnesium. MetS, metabolic syndrome. T2DM, type 2 diabetes mellitus. HTN, hypertension. hypoMg, hypomagnesemia. OR, odds ratio. CI, confidence interval. $\uparrow$, increased. $\downarrow$, decreased. (+), positive. (-), negative. MgO, Mg oxide. HDL-C, high-density lipoprotein cholesterol. LDL-C, low-density lipoprotein cholesterol. TC, total cholesterol. TG, triglycerides. VLDL, very low-density lipoprotein cholesterol. apoA1, apolipoprotein A1. oxLDL, oxidized LDL. RDV, recommended dietary value. $\Delta$, variation. $\mathrm{MgCl}_{2}, \mathrm{Mg}$ chloride. $\mathrm{mg}$, milligrams. g, grams. mL, milliliter. K, potassium. MONW, metabolically obese normal-weight. NW, normal weight.

\subsection{Crosstalk of Magnesium, Chronic Kidney Disease, and Hemodialysis}

A total of 16 studies assessed the crosstalk of $\mathrm{Mg}$, serum lipids, and kidney disorders, focusing on the relationship of serum $\mathrm{Mg}$ with the lipid profile in chronic kidney disease (CKD) or in patients undergoing hemo-/peritoneal dialysis. The impact of dietary $\mathrm{Mg}$ intake or Mg supplementation on serum lipids was also scrutinized.

\subsubsection{Chronic Kidney Disease}

Toprak et al. (2017) evaluated the impact of hypomagnesemia on erectile dysfunction in 372 elderly, non-T2DM, stage 3 and 4 CKD patients and argued that the subjects with hypomagnesemia were more likely to suffer from obesity $(p=0.003)$, MetS $(p=0.026)$, have increased waist circumference $(p=0.043)$ and low HDL-C $(p=0.009)$ [116]. Khatami et al. (2013) evaluated the relationship between serum $\mathrm{Mg}$ and the lipid profile in 103 patients diagnosed with end-stage renal disease who were receiving hemodialysis. Serum $\mathrm{Mg}$ was similar between patients who had a history of dyslipidemia or had received statins, and there were no differences in terms of HDL-C, LDL-C, or apoprotein(a) levels between subjects with low versus high serum Mg concentrations. However, TC $(p=0.03)$ and TG $(p=0.04)$ were elevated in individuals with high serum Mg levels, though no correlations were detected between Mg and TC, TG, LDL-C, HDL-C or apoprotein(a) concentrations [117]. Dey et al. (2015) also evaluated the links between serum Mg concentrations and the lipid profile in 90 patients diagnosed with CKD. CKD subjects had lower serum and urinary $\mathrm{Mg}$ and higher TC, LDL-C, and non-HDL-C $(p<0.001$ for all) versus controls, yet no differences were recorded in terms of HDL-C, TG, or VLDL concentrations. In patients suffering from $C K D$, there was a positive correlation of serum Mg with HDL-C 
$(\mathrm{r}=0.326, p=0.002)$ and negative correlations with TC $(\mathrm{r}=-0.247, p=0.019)$, LDL-C $(\mathrm{r}=-0.303, p=0.004)$, and non-HDL-C $(\mathrm{r}=-0.289, p=0.006)$. Serum Mg also correlated with the Framingham risk score $(\mathrm{r}=-0.939, p<0.001)$, the presence of MetS $(\mathrm{r}=-0.830$, $p<0.001)$ and CKD severity $(r=-0.245, p=0.02)$ [118]. Cambray et al. (2020) analyzed the Mg-lipids-atherosclerosis crosstalk in 1754 CKD patients, revealing that Mg and TG concentrations displayed a tendency to increase ( $p<0.001$ for trend, both groups) and TC, LDL-C, and HDL-C displayed a tendency to decrease $(p<0.001$ for trend for all) as CKD severity advanced toward dialysis. Mg levels were correlated with the presence of T2DM $(\mathrm{r}=-0.070, p=0.003)$, hypertension $(\mathrm{r}=0.053, p=0.028)$, BMI $(\mathrm{r}=-0.053, p=0.027)$, however no associations of Mg with the presence of dyslipidemia or TC, TG, HDL-C, or LDL-c were detected. In the multivariate linear effects model for carotid intima-media thickness, the authors reported associations between the aforementioned marker of atherosclerosis and TC $(\beta=-0.006, \mathrm{SE}=0.003 p=0.02)$, HDL-C $(\beta=0.006, \mathrm{SE}=0.003, p=0.03)$, LDL-C $(\beta=0.006, \mathrm{SE}=0.003, p=0.04)$, and TG $(\beta=0.001, \mathrm{SE}=0.0005, p=0.014)$, but not with $\mathrm{Mg}$ $(\beta=-0.12, \mathrm{SE}=0.099, p=0.23)$. Despite these findings, when looking closely at the interactions of $\mathrm{Mg}$ with serum lipids, namely Mg-TC $(\beta=0.008, \mathrm{SE}=0.003, p=0.011), \mathrm{Mg}-\mathrm{HDL}-\mathrm{C}$ $(\beta=-0.007, \mathrm{SE}=0.003, p=0.016), \mathrm{Mg}-\mathrm{LDL}-\mathrm{C}(\beta=-0.007, \mathrm{SE}=0.003, p=0.03)$, and Mg-TG $(\beta=-0.0014, \mathrm{SE}=0.0005, p=0.01), \mathrm{Mg}$ concentrations and carotid intima-media thickness were associated [119]. In a pilot study conducted on kidney transplant patients suffering from hypomagnesemia, the administration of $\mathrm{Mg}$ oxide significantly decreased $\mathrm{TC}$ and LDL-C, but did not alter TC/HDL-C, TG or apolipoprotein fractions [120].

\subsubsection{Hemodialysis}

Liu et al. (2013) also evaluated the associations between serum $\mathrm{Mg}$ and the lipid profile in hemodialysis patients, revealing that subjects suffering from hypo- versus hypermagnesemia had higher HDL-C $(p<0.05)$ but similar LDL-C, TC, TG, and lipoprotein-a concentrations. Among the aforementioned components of the lipid profile, $\mathrm{Mg}$ levels only correlated with HDL-C $(\mathrm{r}=-0.028, p=0.024)$ [121]. Hemodialysis reduced serum Mg levels $(1.11 \pm 0.14 \mathrm{mmol} / \mathrm{L}$ versus $0.97 \pm 0.10 \mathrm{mmol} / \mathrm{L}, p<0.05)$ in 148 , with Han et al. (2020) reporting that pre-hemodialysis $\mathrm{Mg}$ concentrations are correlated with TC [ $\beta=0.03(0.006$, $0.05), p=0.016 ; \beta=-0.003$ (-0.004, -0.0009$), p=0.003 ; \beta=0.03$ (0.006, 0.05), $p=0.02$ ] according to different un/adjusted models [122]. According to Mortazavi et al. (2013)'s $\mathrm{RCT}$, a 6-month Mg supplementation reduced LDL-C ( $p=0.04)$ but did not affect HDL-C, TC, or TG in 54 Iranian subjects undergoing hemodialysis [123]. Shimohata et al. (2019) investigated 83 patients without T2DM who were undergoing hemodialysis in order to assess the link between mortality and serum $\mathrm{Mg}$ concentrations and revealed an univariate association between Mg levels and HDL-C $(r=0.284, p=0.009)$ but not LDL-C $(r=0.075$, $p=0.499)$. However, when analyzed by multiple regression, the Mg-HDL-C association did not reach statistical significance (coefficient: $0.004 ; \beta=0.196 ; p=0.105$ ). Nevertheless, the mortality was higher $(\log$ rank $=4.951 ; p=0.026)$ in patients with $\mathrm{Mg}<2.5 \mathrm{mg} / \mathrm{dL}$ versus $\geq 2.5 \mathrm{mg} / \mathrm{dL}$ [124]. Robles et al. (1997) have also shown that in patients receiving hemodialysis there are significant correlations of low serum Mg levels with increased LDLC, VLDL-C, and apoB levels $(p<0.001)$ [125]. Tamura et al. (2019) scrutinized 392 patients undergoing hemodialysis for 4 years and concluded that low $\mathrm{Mg}$ levels are associated with higher mortality rates. In addition, in their paper, there were positive $\mathrm{Mg}-\mathrm{TC}(p=0.257)$, and Mg-TG ( $p=0.0279)$ associations. However, HDL-C remained unchanged regardless of the $\mathrm{Mg}$ concentrations $(p=0.097)$ [126]. Ansari et al. (2012) observed significant positive correlations between serum Mg and lipoprotein-a $(\mathrm{r}=0.40, p<0.007)$, HDL-C ( $\mathrm{r}=0.31$, $p<0.01)$ and TG $(\mathrm{r}=0.35, p<0.005)$, but not with LDL-C or TC in 50 patients receiving hemodialysis [127]. Similarly, Baradaran and Nasri (2004) studied 36 hemodialysis subjects and unmasked significant positive correlations of serum $\mathrm{Mg}$ with lipoprotein $(\mathrm{a})(\mathrm{r}=0.65$, $p<0.05)$ and TG $(r=0.32, p<0.05)$, but not with TC, HDL-C, or LDL-C [128]. HDL-C $(\mathrm{r}=0.315, p=0.003)$ was positively associated with Mg concentrations in Ikee et al. (2016)'s cross-sectional study which included eighty-six patients undergoing hemodialysis [129]. 
Mitwalli et al. (2016) studied the significance of lower Mg levels in the serum of Saudi dialysis patients. One hundred and fifteen patients partook in this retrospective study: seventy patients were on hemodialysis and forty-five were on peritoneal dialysis. The subjects' serum values of $\mathrm{Mg}, \mathrm{TC}$, and TG were determined, showing that patients that underwent peritoneal dialysis had lower $\mathrm{Mg}$ levels compared to hemodialysis patients. The correlation studies did not find statistically significant associations between $\mathrm{Mg}$ and TC or TG variations [130]. While studying the association of hypomagnesemia with increased mortality among patients that underwent peritoneal dialysis in a research which included two hundred and fifty three subjects, Cai et al. (2016) reported a positive association between low serum Mg and TG $(r=0.160, p=0.011)$, but the correlation with TC did not reach statistical significance $(p=0.929)$ [131].

The most relevant information of this subsection are summarized in Table 6.

Table 6. Interplay of magnesium, serum lipids, and the kidney.

\begin{tabular}{|c|c|c|c|c|}
\hline Author and Year & Condition & $\begin{array}{l}\text { Number of } \\
\text { Patients }\end{array}$ & $\begin{array}{l}\text { Method of Mg } \\
\text { Determination }\end{array}$ & Main Results \\
\hline Toprak et al. (2017) [116] & $\begin{array}{c}\text { stage } 3 \text { and } 4 \text { CKD, erectile } \\
\text { dysfunction }\end{array}$ & 372 & Unspecified & $\begin{array}{l}\text { hypoMg: } \uparrow \text { obesity }(p=0.003), \uparrow \text { MetS } \\
(p=0.026), \downarrow \text { HDL-C }(p=0.009)\end{array}$ \\
\hline Khatami et al. (2013) [117] & $\begin{array}{c}\text { end-stage renal disease }+ \\
\text { HD }\end{array}$ & 103 & $\begin{array}{c}\text { Serum } \\
\text { (spectrophotometry) }\end{array}$ & $\uparrow \mathrm{Mg}=\uparrow \mathrm{TC}(p=0.03), \uparrow \mathrm{TG}(p=0.04)$ \\
\hline Dey et al. (2015) [118] & CKD & 180 & $\begin{array}{l}\text { Serum } \\
\text { (chemical } \\
\text { autoanalyzer) }\end{array}$ & $\begin{array}{c}\downarrow \text { serum and urinary Mg } \\
\uparrow \mathrm{TC}, \mathrm{LDL}-\mathrm{C}, \text { non-HDL-C }(p<0.001 \text { for all }) \\
(+) \text { correlation of serum Mg and HDL-C } \\
(\mathrm{r}=0.326, p=0.002) \\
(-) \text { correlations of serum Mg and TC } \\
(\mathrm{r}=-0.247, p=0.019), \mathrm{LDL}-\mathrm{C}(\mathrm{r}=-0.303, \\
p=0.004), \text { non-HDL-C }(\mathrm{r}=-0.289, p=0.006), \\
\text { Framingham risk score }(\mathrm{r}=-0.939, p<0.001), \\
\text { the presence of MetS }(\mathrm{r}=-0.830, p<0.001), \\
\text { CKD severity }(\mathrm{r}=-0.245, p=0.02)\end{array}$ \\
\hline Cambray et al. (2020) [119] & CKD & 1754 & $\begin{array}{l}\text { Serum } \\
(\mathrm{Mg} \text { reagent })\end{array}$ & $\begin{array}{c}\uparrow \mathrm{CKD} \text { severity }=\uparrow \mathrm{Mg} \text { and } \uparrow \mathrm{TG}(p<0.001 \\
\text { for trend) } \\
\uparrow \mathrm{CKD} \text { severity }=\downarrow \mathrm{TC}, \mathrm{LDL}-\mathrm{C}, \mathrm{HDL}-\mathrm{C} \\
(p<0.001 \text { for }) \\
\text { associations of } \mathrm{Mg} \text { with T2DM }(\mathrm{r}=-0.070, \\
p=0.003), \mathrm{HTN}(\mathrm{r}=0.053, p=0.028), \mathrm{BMI} \\
(\mathrm{r}=-0.053, p=0.027) \\
\text { association of CIMT and } \mathrm{Mg}-\mathrm{TC}(\beta=0.008, \\
\mathrm{SE}=0.003, p=0.011), \mathrm{Mg}-\mathrm{HDL}-\mathrm{C} \\
(\beta=-0.007, \mathrm{SE}=0.003, p=0.016), \\
\mathrm{Mg}-\mathrm{LDL}-\mathrm{C}(\beta=-0.007, \mathrm{SE}=0.003, p=0.03), \\
\mathrm{Mg}-\mathrm{TG}(\beta=-0.0014, \mathrm{SE}=0.0005, p=0.01) \\
\text { interactions }\end{array}$ \\
\hline Gupta et al. (1999) [120] & kidney transplant & 14 & $\begin{array}{c}\text { Serum } \\
\text { (method unspecified) }\end{array}$ & MgO in hypoMg: $\downarrow$ TC, $\downarrow$ LDL-C \\
\hline Liu et al. (2013) [121] & HD & 98 & $\begin{array}{l}\text { Serum } \\
\text { (colorimetric assay) }\end{array}$ & $\begin{array}{c}\uparrow \text { HDL-C }(p<0.05) \text { in hypo- versus hyperMg } \\
\text { similar LDL-C, TC, TG, lipoprotein-a } \\
(-) \text { Mg-HDL-C correlation }(\mathrm{r}=-0.028, \\
\quad p=0.024)\end{array}$ \\
\hline Han et al. (2020) [122] & HD & 148 & $\begin{array}{l}\text { Serum } \\
\text { (toluidine blue assay) }\end{array}$ & $\begin{array}{c}\mathrm{HD} \downarrow \mathrm{Mg}(p<0.05) \\
\text { pre-HD Mg correlated with TC }[\beta=0.03 \\
(0.006,0.05), p=0.016 ; \beta=-0.003(-0.004, \\
-0.0009), p=0.003 ; \beta=0.03(0.006,0.05), \\
p=0.02]\end{array}$ \\
\hline $\begin{array}{l}\text { Shimohata et al. (2019) } \\
\text { [124] }\end{array}$ & HD & 83 & $\begin{array}{l}\text { Serum } \\
\text { (chemical } \\
\text { autoanalyzer) }\end{array}$ & $\begin{array}{l}\text { Mg-HDL-C association }(\mathrm{r}=0.284, p=0.009) \\
\text { multiple regression: no Mg-HDL-C } \\
(\text { coefficient: } 0.004 ; \beta=0.196 ; p=0.105) \\
\uparrow \text { mortality for } \mathrm{Mg}<2.5 \text { versus } \geq 2.5 \mathrm{mg} / \mathrm{dL} \\
\quad(\log \text { rank }=4.951 ; p=0.026)\end{array}$ \\
\hline Robles et al. (1997) [125] & HD & 25 & $\begin{array}{c}\text { Serum } \\
\text { (method unspecified) }\end{array}$ & $\begin{array}{c}\downarrow \text { Mg correlated with } \uparrow \text { LDL-C, } \uparrow \text { VLDL-C, } \uparrow \\
\text { apoB }(p<0.001)\end{array}$ \\
\hline Tamura et al. (2019) [126] & HD & 392 & $\begin{array}{l}\text { Serum } \\
\text { (method unspecified) }\end{array}$ & $\begin{array}{c}\downarrow \mathrm{Mg} \text { associated with } \uparrow \text { mortality } \\
(+) \mathrm{Mg}-\mathrm{TC}(p=0.257) \text { and Mg-TG } \\
(p=0.0279) \text { associations }\end{array}$ \\
\hline
\end{tabular}


Table 6. Cont.

\begin{tabular}{ccccc}
\hline Author and Year & Condition & $\begin{array}{c}\text { Number of } \\
\text { Patients }\end{array}$ & $\begin{array}{c}\text { Method of Mg } \\
\text { Determination }\end{array}$ & Main Results \\
\hline Ansari et al. (2012) [127] & HD & 50 & $\begin{array}{c}\text { Serum } \\
\text { (standard method) }\end{array}$ & $\begin{array}{c}\text { (+) correlations of Mg and lipoprotein-a } \\
(\mathrm{r}=0.40, p<0.007), \mathrm{HDL}-\mathrm{C}(\mathrm{r}=0.31, p<0.01), \\
\mathrm{TG}(\mathrm{r}=0.35, p<0.005)\end{array}$ \\
\hline $\begin{array}{c}\text { Baradaran and Nasri } \\
\text { (2004) [128] }\end{array}$ & HD & 36 & $\begin{array}{c}\text { Dialysis fluid } \\
\text { (method unspecified) }\end{array}$ & $\begin{array}{c}(+) \text { correlations of Mg and lipoprotein (a) } \\
(\mathrm{r}=0.65, p<0.05), \mathrm{TG}(\mathrm{r}=0.32, p<0.05)\end{array}$ \\
\hline Ikee et al. (2016) [129] & HD & 86 & $\begin{array}{c}\text { Serum } \\
\text { (xylidyl blue test) }\end{array}$ & $\begin{array}{c}(+) \text { association of Mg and. HDL-C ( } \mathrm{r}=0.315, \\
p=0.003)\end{array}$ \\
\hline Mitwalli et al. (2016) [130] & HD, PD & 115 & $\begin{array}{c}\text { Dialysis fluid } \\
\text { (Mg reagent) }\end{array}$ & $\begin{array}{c}\text { Mg in PD compared to HD } \\
\text { no assiations of Mg and TC or TG } \\
\text { variations }\end{array}$ \\
\hline Cai et al. (2016) [131] & PD & 253 & $\begin{array}{c}\text { Dialysis fluid } \\
\text { (chemical } \\
\text { autoanalyzer) }\end{array}$ & $\begin{array}{c}(+) \text { association of hypoMg and TG (r }=0.160, \\
p=0.011)\end{array}$ \\
\hline
\end{tabular}

$\mathrm{Mg}$, magnesium. MetS, metabolic syndrome. T2DM, type 2 diabetes mellitus. HTN, hypertension. hypoMg, hypomagnesemia. OR, odds ratio. CI, confidence interval. $\uparrow$, increased. $\downarrow$, decreased. $(+)$, positive. $(-)$, negative. $\sigma^{\top}$, male., , female. $\mathrm{MgO}, \mathrm{Mg}$ oxide. $\mathrm{HDL}-\mathrm{C}$, high-density lipoprotein cholesterol. LDL-C, low-density lipoprotein cholesterol. TC, total cholesterol. TG, triglycerides. VLDL, very low-density lipoprotein cholesterol. apoA1, apolipoprotein A1. oxLDL, oxidized LDL. RDV, recommended dietary value. $\Delta$, variation. $\mathrm{MgCl}_{2}, \mathrm{Mg}$ chloride. mg, milligrams. g, grams. mL, milliliter. $\mathrm{K}$, potassium. MONW, metabolically obese normal-weight. NW, normal weight. CKD, chronic kidney disease. HD, hemodialysis. PD, peritoneal dialysis. CIMT, carotid intima-media thickness.

Finally, the effects of $\mathrm{Mg}$ supplementation (alone, in combination or as part of dietary interventions) as depicted in RCTs are reported in Table 7.

Table 7. Effects of Mg supplementation in RCTs.

\begin{tabular}{|c|c|c|c|c|c|c|}
\hline $\begin{array}{c}\text { Authors and } \\
\text { Year }\end{array}$ & Country & Intervention & Duration & Condition & No. Subjects & Effects on the Lipid Profile \\
\hline $\begin{array}{c}\text { Itoh et al. (1997) } \\
\text { [13] }\end{array}$ & Japan & $\begin{array}{c}\mathrm{Mg}(\mathrm{OH})_{2} \\
\sim 411-548 \mathrm{mg} \\
\mathrm{Mg} / \text { day } \\
\end{array}$ & 4 weeks & Healthy & 33 & $\begin{array}{l}\text { HDL-C, apoA1: } \uparrow \\
\text { LDL-C, TC/HDL-C: } \downarrow\end{array}$ \\
\hline $\begin{array}{l}\text { Marken et al. } \\
\text { (1989) [14] }\end{array}$ & USA & 800 mg/day MgO & 60 days & Healthy & 50 & $\begin{array}{c}\text { TC, HDL-C, LDL-C, VLDL, } \\
\text { TG: no effect }\end{array}$ \\
\hline $\begin{array}{l}\text { Aslanabadi et al. } \\
\text { (2014) [18] }\end{array}$ & Iran & $\begin{array}{l}\text { 1L/day Mg-rich } \\
\text { miner water }\end{array}$ & 1 month & Dyslipidemia & 69 & $\begin{array}{c}\text { TC, HDL-C, LDL-C, TG: no } \\
\text { effect }\end{array}$ \\
\hline $\begin{array}{c}\text { Rodriguez- } \\
\text { Moran and } \\
\text { Guerrero-Romero } \\
\text { (2014) [35] }\end{array}$ & Mexico & $\begin{array}{c}30 \mathrm{~mL} / \text { day } \\
\mathrm{MgCl}_{2} 5 \% \\
\text { solution } \sim 382 \mathrm{mg} \\
\mathrm{Mg}\end{array}$ & 4 months & $\begin{array}{c}\text { MONW } \\
+ \\
\text { Hypomagne- } \\
\text { semia }\end{array}$ & 47 & $\begin{array}{l}\text { HDL-C: } \uparrow \\
\text { TG: } \downarrow\end{array}$ \\
\hline $\begin{array}{c}\text { Joris et al. (2017) } \\
\text { [36] }\end{array}$ & The Netherlands & 350 mg/day Mg & 24 weeks & Overweight/Obesity & 52 & $\begin{array}{c}\text { TC, HDL-C, LDL-C, TG, } \\
\text { non-esterified fatty acids: no } \\
\text { effect }\end{array}$ \\
\hline $\begin{array}{l}\text { Solati et al. (2019) } \\
\text { [38] }\end{array}$ & Iran & $\begin{array}{c}\text { herbal } \\
\text { supplement } \\
\sim 300 \mathrm{mg} / \text { day } \\
\mathrm{MgSO}_{4}\end{array}$ & 6 months & Overweight & 70 & $\begin{array}{l}\text { HDL-C, HDL-C/TG: } \uparrow \\
\text { LDL-C, TG: } \downarrow\end{array}$ \\
\hline $\begin{array}{l}\text { Jamilian et al. } \\
\text { (2019) [41] }\end{array}$ & Iran & $\begin{array}{c}250 \mathrm{mg} / \text { day } \mathrm{Mg}+ \\
400 \mathrm{mg} / \text { day } \\
\text { vitamin E }\end{array}$ & 12 weeks & PCOS & 60 & $\begin{array}{c}\text { TG, VLDL: } \downarrow \\
\text { HDL-C, LDL-C, TC/HDL-C } \\
\text { no effect }\end{array}$ \\
\hline $\begin{array}{l}\text { Jamilian et al. } \\
\text { (2017) [42] }\end{array}$ & Iran & $\begin{array}{c}200 \mathrm{mg} / \text { day } \mathrm{Mg}+ \\
800 \mathrm{mg} / \mathrm{day} \mathrm{Ca}+ \\
8 \mathrm{mg} / \text { day } \mathrm{Zn}+ \\
400 \mathrm{IU} \text { vitamin D }\end{array}$ & 12 weeks & PCOS & 60 & $\begin{array}{l}\text { TC, TG, VLDL: } \downarrow \\
\text { HDL-C, LDL-C: no effect }\end{array}$ \\
\hline $\begin{array}{l}\text { Karandish et al. } \\
\text { (2013) [43] }\end{array}$ & Iran & $\begin{array}{l}350 \mathrm{mg} / \text { day } \mathrm{Mg}+ \\
\text { low-calorie diet }+ \\
\text { physical exercise }\end{array}$ & 90 days & NAFLD & 68 & $\begin{array}{c}\text { TC, HDL-C, LDL-C, TG: no } \\
\text { effect }\end{array}$ \\
\hline $\begin{array}{l}\text { de Lourdes Lima } \\
\text { de Souza e Silva } \\
\text { (2014) [53] }\end{array}$ & Brazil & $\begin{array}{l}400 \mathrm{mg} / \text { day } \mathrm{Mg} \\
\text { chelate }\end{array}$ & 12 weeks & MetS & 72 & $\begin{array}{c}\text { TC, HDL-C, LDL-C, TG: no } \\
\text { effect }\end{array}$ \\
\hline $\begin{array}{l}\text { Hamedifard et al. } \\
\quad(2020)[80]\end{array}$ & Iran & $\begin{array}{c}250 \mathrm{mg} / \text { day } \mathrm{MgO} \\
+150 \mathrm{mg} / \text { day } \\
\mathrm{ZnSO}_{4} \\
\end{array}$ & 12 weeks & $\mathrm{T} 2 \mathrm{DM}+\mathrm{CHD}$ & 60 & $\begin{array}{c}\text { HDL-C: } \uparrow \\
\text { TC, TC/HDL-C, LDL-C, } \\
\text { VLDL, TG: no effect }\end{array}$ \\
\hline
\end{tabular}


Table 7. Cont.

\begin{tabular}{|c|c|c|c|c|c|c|}
\hline $\begin{array}{l}\text { Authors and } \\
\text { Year }\end{array}$ & Country & Intervention & Duration & Condition & No. Subjects & Effects on the Lipid Profile \\
\hline $\begin{array}{l}\text { Rashvand et al. } \\
\text { (2019) [82] }\end{array}$ & Iran & $\begin{array}{l}500 \mathrm{mg} / \text { day } \mathrm{MgO} \\
+1000 \mathrm{mg} / \text { day } \\
\text { choline bitartrate }\end{array}$ & 2 months & T2DM & 96 & $\begin{array}{c}\text { HDL-C: } \uparrow \\
\text { TG: } \downarrow \\
\text { TC, LDL-C } / \text { HDL-C, LDL-C: } \\
\text { no effect }\end{array}$ \\
\hline $\begin{array}{l}\text { Whitfield et al. } \\
\text { (2016) [83] }\end{array}$ & New Zealand & $\begin{array}{l}53.5 \mathrm{~g} \mathrm{Mg}, \mathrm{Cr} \\
\text { cinnamon } \\
\text { enriched honey }\end{array}$ & 40 days & T2DM & 12 & $\begin{array}{c}\text { TC, LDL-C: } \downarrow \\
\text { HDL-C, TG: no effect }\end{array}$ \\
\hline $\begin{array}{l}\text { Ham and Shon } \\
\text { (2020) [87] }\end{array}$ & Korea & $\begin{array}{l}440 \mathrm{~mL} / \text { day } \\
\text { Mg-enriched } \\
\text { deep sea water }\end{array}$ & 8 weeks & Prediabetes & 74 & $\begin{array}{l}\text { TC, LDL-C: } \downarrow \\
\text { HDL-C, TG: no effect }\end{array}$ \\
\hline $\begin{array}{l}\text { Cosaro et al. } \\
(2014)[88]\end{array}$ & Italy & $\begin{array}{l}16.2 \mathrm{mmol} / \text { day } \\
\mathrm{Mg} \text { pidolate }\end{array}$ & 8 weeks & $\begin{array}{l}\text { Healthy men with } \\
\text { a positive family } \\
\text { history for } \\
\text { T2DM/MetS }\end{array}$ & 14 & $\begin{array}{l}\text { TC, HDL-C, LDL-C, TG: no } \\
\text { effect }\end{array}$ \\
\hline $\begin{array}{l}\text { Asemi et al. } \\
\text { (2015) [89] }\end{array}$ & Iran & 250 mg/day $\mathrm{MgO}$ & 6 weeks & $\begin{array}{l}\text { Gestational } \\
\text { diabetes + Mg } \\
\text { deficiency }\end{array}$ & 70 & $\begin{array}{c}\text { HDL-C, LDL-C, TC/HDL-C: } \\
\text { no effect }\end{array}$ \\
\hline $\begin{array}{l}\text { Navarrete-Cortes } \\
\text { et al. (2014) [90] }\end{array}$ & Mexico & $\begin{array}{c}360 \mathrm{mg} / \text { day } \mathrm{Mg} \\
\text { lactate }\end{array}$ & 3 months & $\begin{array}{l}\text { T2DM + } \\
\text { normomagne- } \\
\text { semia }\end{array}$ & 98 & $\begin{array}{l}\text { TC, HDL-C, LDL-C, TG: no } \\
\text { effect }\end{array}$ \\
\hline $\begin{array}{l}\text { Guerrero-Romero } \\
\text { et al. (2015) [91] }\end{array}$ & Mexico & $\begin{array}{c}30 \mathrm{~mL} / \text { day } \\
\mathrm{MgCl}_{2} 5 \% \\
\text { solution } \sim 382 \mathrm{mg} \\
\text { of } \mathrm{Mg}\end{array}$ & 4 months & $\begin{array}{c}\text { Prediabetes + } \\
\text { hypomagnesemia }\end{array}$ & 116 & $\begin{array}{l}\text { HDL-C: } \uparrow \\
\text { TG: } \downarrow\end{array}$ \\
\hline $\begin{array}{l}\text { Solati et al. (2014) } \\
\text { [92] }\end{array}$ & Iran & $\begin{array}{c}300 \mathrm{mg} / \text { day } \\
\mathrm{MgSO}_{4}\end{array}$ & 3 months & $\mathrm{T} 2 \mathrm{DM}$ & 54 & $\begin{array}{l}\text { LDL-C, non-HDL-C: } \downarrow \\
\text { TC, HDL-C, TG: no effect }\end{array}$ \\
\hline $\begin{array}{l}\text { De Valk et al. } \\
\text { (1998) [93] }\end{array}$ & The Netherlands & 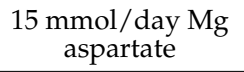 & 3 months & Controlled T2DM & 50 & TC, HDL-C, TG: no effect \\
\hline $\begin{array}{l}\text { Talari et al. (2019) } \\
\text { [95] }\end{array}$ & Iran & 250 mg/day MgO & 24 weeks & $\mathrm{T} 2 \mathrm{DM}+\mathrm{HD}$ & 54 & TC, LDL-C $\downarrow$ \\
\hline $\begin{array}{l}\text { Afzali et al. (2019) } \\
\text { [96] }\end{array}$ & Iran & $\begin{array}{c}250 \mathrm{mg} / \text { day } \mathrm{MgO} \\
+400 \mathrm{IU} / \text { day } \\
\text { vitamin } \mathrm{E}\end{array}$ & 12 weeks & $\begin{array}{l}\mathrm{T} 2 \mathrm{DM} \text { + diabetic } \\
\text { foot }\end{array}$ & 57 & $\begin{array}{c}\text { HDL-C: } \uparrow \\
\text { LDL-C, TG: } \downarrow\end{array}$ \\
\hline $\begin{array}{l}\text { Karamali M. et al. } \\
\text { (2018) [98] }\end{array}$ & Iran & $\begin{array}{c}200 \mathrm{mg} / \text { day } \mathrm{Mg}+ \\
800 \mathrm{mg} / \text { day } \mathrm{Ca}+ \\
8 \mathrm{mg} / \text { day } \mathrm{Zn}+ \\
400 \mathrm{IU} \text { vitamin D }\end{array}$ & 6 weeks & $\begin{array}{l}\text { Gestational } \\
\text { diabetes }\end{array}$ & 60 & VLDL, TG: $\downarrow$ \\
\hline $\begin{array}{l}\text { Sadeghian et al. } \\
\text { (2020) [99] }\end{array}$ & Iran & 250 mg/day $\mathrm{MgO}$ & 12 weeks & $\begin{array}{c}\text { T2DM } \\
\text { nephropathy }\end{array}$ & 80 & $\begin{array}{l}\text { TC, LDL-C, HDL-C, } \\
\text { TC/HDL-C, TG: no effect }\end{array}$ \\
\hline $\begin{array}{l}\text { Farshidi et al. } \\
\text { (2020) [105] }\end{array}$ & Iran & $\begin{array}{l}300 \mathrm{mg} / \text { day } \\
\mathrm{MgSO}_{4}\end{array}$ & 6 months & CHD & 64 & $\begin{array}{c}\text { HDL-C: } \uparrow \\
\text { oxLDL, TC } / \text { HDL-C, LDL-C: } \\
\downarrow\end{array}$ \\
\hline $\begin{array}{l}\text { Zemel et al. (1990) } \\
\text { [109] }\end{array}$ & USA & $\begin{array}{l}40 \mathrm{mmol} / \text { day } \mathrm{Mg} \\
\text { aspartate }\end{array}$ & 3 months & Hypertension & 13 & $\begin{array}{l}\text { TC, HDL-C, LDL-C, TG: no } \\
\text { effect }\end{array}$ \\
\hline $\begin{array}{c}\text { Guerrero-Romero } \\
\text { and Rodriguez- } \\
\text { Moran (2008) } \\
{[111]}\end{array}$ & Mexico & $\begin{array}{l}2.5 \mathrm{~g} / \text { day } \mathrm{MgCl}_{2} \\
(450 \mathrm{mg} \mathrm{Mg})\end{array}$ & 4 months & Hypertension & 82 & $\begin{array}{l}\text { HDL-C: } \uparrow \\
\text { TG: no effect }\end{array}$ \\
\hline $\begin{array}{l}\text { Cunha et al. } \\
\text { (2016) [113] }\end{array}$ & Brazil & 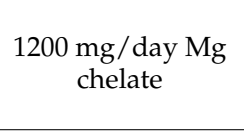 & 6 months & $\begin{array}{l}\text { Hypertension in } \\
\text { women } \\
\text { prescribed } \\
\text { thiazides }\end{array}$ & 35 & HDL-C, LDL-C: no effect \\
\hline $\begin{array}{l}\text { Mortazavi et al. } \\
\text { (2013) [123] }\end{array}$ & Iran & $\begin{array}{l}440 \mathrm{mg} \mathrm{MgO} \\
\text { x3/week }\end{array}$ & 6 months & $\mathrm{HD}$ & 54 & $\begin{array}{c}\text { LDL-C: } \downarrow \\
\text { TC, HDL-C, TG: no effect }\end{array}$ \\
\hline
\end{tabular}

$\mathrm{Mg}$, magnesium. RCTs, randomized clinical trials. $\uparrow$, increased. $\downarrow$, decreased. mg, milligrams. g, grams. USA, United States of America. $\mathrm{mL}$, milliliter. $\mathrm{Mg}(\mathrm{OH})_{2}, \mathrm{Mg}$ hydroxide. $\mathrm{MgO}, \mathrm{Mg}$ oxide. $\mathrm{MgCl}_{2}, \mathrm{Mg}$ chloride. Ca, calcium. $\mathrm{Zn}$, Zinc. $\mathrm{Cr}$, chromium. IU, international units. MONW, metabolically obese normal-weight. PCOS, polycystic ovary syndrome. NAFLD, nonalcoholic fatty liver disease. MetS, metabolic syndrome. T2DM, type 2 diabetes mellitus. CHD, coronary heart disease. HD, hemodialysis. HDL-C, high-density lipoprotein cholesterol. LDL-C, low-density lipoprotein cholesterol. TC, total cholesterol. TG, triglycerides. VLDL, very low-density lipoprotein cholesterol. apoA1, apolipoprotein A1. oxLDL, oxidized LDL. 


\section{Discussion}

In this systematic review, we focused on depicting the relationship between $\mathrm{Mg}$ levels and serum lipids in dyslipidemia and associated disorders. We analyzed a total of 124 studies conducted on patients diagnosed with dyslipidemia, MetS, T2DM, cardiovascular or kidney disorders, yet due to the heterogeneity of the analyzed papers it is difficult to conclude to which extent $\mathrm{Mg}$ levels are linked to serum lipids concentrations. Although we aimed to investigate both "classical" (TC, TG, HDL-C and LDL-C) and "non-classical" components (apolipoproteins, $\mathrm{Lp}(\mathrm{a})$, oxLDL etc.) of the lipid profile, most studies were focused on examining the crosstalk of Mg levels and TC, TG, HDL-C, and LDL-C.

$\mathrm{Mg}$ deficits may arise both from primary (insufficient intake, decreased absorption or elevated excretion) and secondary causes, e.g., disorders that accompany the advancement in age, several comorbidities (T2DM, MetS) or it can occur due to the use of certain medications such as loop diuretics [132]. In addition, particular attention should be given to the methods employed in the measurement of Mg concentrations. Barbagallo et al. (2014) demonstrated that, in elderly patients diagnosed with T2DM, serum ionized rather than total serum $\mathrm{Mg}$ may emerge as a superior predictor of the subclinical deficit of this micronutrient. In addition, they also detected that TG may be a confounding factor in the crosstalk between $\mathrm{Mg}$ levels and markers of glucose metabolism. For example, after multiple adjustments for TG, BMI, and glomerular filtration rate, the associations of serum total Mg with FPG and $\mathrm{HbA1c}$, respectively, failed to reach statistical significance. However, serum-ionized $\mathrm{Mg}$ remained associated with these variables despite multiple adjustments [133]. Moreover, in their recent umbrella review of systematic reviews and meta-analyses of observational and intervention studies focused on the crosstalk between $\mathrm{Mg}$ concentrations and health outcomes, Veronese et al. (2019) evidenced that an elevated intake of this micronutrient can result in a reduction of the risk of both stroke and T2DM. However, $\mathrm{Mg}$ intake was not linked to any other cardiovascular endpoints based on their results [134].

The potential lipid-lowering effects of $\mathrm{Mg}$ warrant further investigation, with a myriad of studies linking the serum concentrations of this micronutrient to cardiometabolic disorders, e.g., obesity, T2DM, MetS, cardiovascular disorders, neurological ailments, and even cancer, all of which are worldwide public health threats $[5,135,136]$. Mg supplements stand out as one of the most popular supplements in Europe and the United States [137]. In particular, $\mathrm{Mg}$ orotate supplementation, due to the Mg-fixing capacity of this salt, has exerted health benefits $[137,138]$. For example, in an RCT, patients with heart failure who were prescribed $\mathrm{Mg}$ orotate had better 1-year survival versus subjects receiving placebo [138]. Similarly, patients diagnosed with concomitant heart failure and hypertension who were administered $\mathrm{Mg}$ orotate registered a decrease in both blood pressure and $\mathrm{N}$-terminal (NT)-pro hormone BNP (NT-proBNP) [139].

In terms of $\mathrm{Mg}$ supplementation, the most reliable data included in our paper were obtained from 29 RCTs with a total number of 1724 subjects who received different forms of $\mathrm{Mg}$ supplementation for a period of time ranging from 4 to 24 weeks [13,14,18,35,36,38, $41-43,53,80,82,83,87-93,95,96,98,99,105,109,111,113,123]$. Overall, the vast majority of the analyzed RCTs reported no variations in HDL-C $(n=19)$, LDL-C $(n=16)$, TG $(n=17)$, TC $(\mathrm{n}=14)$, TC/HDL-C $(\mathrm{n}=4)$, VLDL $(\mathrm{n}=2)$, or LDL-C/HDL-C $(\mathrm{n}=1)$. However, some RCTs reported elevations of the HDL-C $(\mathrm{n}=8)$, apoA1 $(\mathrm{n}=1)$, or HDL-C/TG $(\mathrm{n}=1)$, as well as reductions in LDL-C $(n=7)$, TC $(n=4)$, TG $(n=7)$, TC/HDL-C $(n=2)$, or VLDL $(n=3)$ in the participants exposed to the Mg intervention $[13,14,18,35,36,38,41-43,53,80,82,83,87-$ $93,95,96,98,99,105,109,111,113,123]$.

Our systematic review has several strengths and limitations. A major strength of our manuscripts is that we systematically analyzed a considerable number of studies that focused on the assessment of the relationship between $\mathrm{Mg}$ levels and serum lipids concentrations. Although lengthy, we strived to summarize all the available evidence regarding this research question and clarify the crosstalk between $\mathrm{Mg}$ and serum lipids in dyslipidemia and associated disorders. We also reported data derived from RCTs conducted 
with the purpose of evaluating the impact of $\mathrm{Mg}$ supplementation on serum lipids values. However, due to multiple reasons (the data analyzed was extremely heterogeneous, most studies included small sample sizes and no control group, some studies assessed serum $\mathrm{Mg}$ whereas other assessed hair or urinary $\mathrm{Mg}$ concentrations, the methods employed to measure $\mathrm{Mg}$ levels were heterogeneous, the crosstalk between $\mathrm{Mg}$ and serum lipids was evaluated in a myriad of disorders), we did not perform a meta-analysis of the gathered evidence. Thus, further research is needed to clarify the relationship between $\mathrm{Mg}$ and serum lipids levels, as well as the effects of $\mathrm{Mg}$ supplementation on the lipid metabolism.

\section{Conclusions}

$\mathrm{Mg}$ remains an important micronutrient for human health, and its putative role in the pathogenesis of dyslipidemia and associated disorders, i.e., MetS, T2DM and cardiovascular disease, has been documented in a myriad of studies. However, the mechanisms activated by $\mathrm{Mg}$ in its interplay with serum lipids have been elucidated, and further research is warranted to explore the lipid-lowering effects of $\mathrm{Mg}$ supplementation or whether a higher dietary intake of this element might emerge as a spearhead in the therapeutic armamentarium of dyslipidemia and closely linked diseases.

Author Contributions: Conceptualization, M.-A.G. and C.C.D.; methodology, M.-A.G.; software, M.A.G., E.-C.D., M.-A.C., and N.-I.A.; validation, M.-A.G., E.-C.D., M.-A.C., and N.-I.A.; formal analysis, M.-A.G., E.-C.D., M.-A.C., and N.-I.A.; investigation, M.-A.G., E.-C.D., M.-A.C., and N.-I.A.; resources, M.-A.G., E.-C.D., M.-A.C., and N.-I.A.; data curation, M.-A.G., E.-C.D., M.-A.C., and N.-I.A.; writingoriginal draft preparation, M.-A.G., E.-C.D., M.-A.C., N.-I.A., and A.M.A.S.; writing-review and editing, M.-A.G., A.M.G., and C.C.D.; visualization, M.-A.G. and C.C.D.; supervision, M.-A.G. and C.C.D.; project administration, M.-A.G. and C.C.D.; funding acquisition, A.M.A.S., C.C.D. All authors have read and agreed to the published version of the manuscript.

Funding: This research received no external funding.

Conflicts of Interest: The authors declare no conflict of interest.

\section{References}

1. Lu, Y.; Wang, P.; Zhou, T.; Lu, J.; Spatz, E.S.; Nasir, K.; Jiang, L.; Krumholz, H.M. Comparison of Prevalence, Awareness, Treatment, and Control of Cardiovascular Risk Factors in China and the United States. J. Am. Heart Assoc. 2018, 7, e007462. [CrossRef] [PubMed]

2. Epingeac, M.E.; Gaman, M.A.; Diaconu, C.C.; Gaman, A.M. Crosstalk between Oxidative Stress and Inflammation in Obesity. Rev. Chim. 2020, 71, 228-232. [CrossRef]

3. Munteanu, M.A.; Gheorghe, G.; Stanescu, A.M.A.; Bratu, O.G.; Diaconu, C.C. What Is New Regarding the Treatment of Dyslipidemia in the 2019 European Society of Cardiology Guidelines? Arch. Balk. Med. Union 2019, 54, 749-752. [CrossRef]

4. Orlova, S.; Dikke, G.; Pickering, G.; Konchits, S.; Starostin, K.; Bevz, A. Magnesium Deficiency Questionnaire: A New NonInvasive Magnesium Deficiency Screening Tool Developed Using Real-World Data from Four Observational Studies. Nutrients 2020, 12, 2062. [CrossRef] [PubMed]

5. Piuri, G.; Zocchi, M.; Della Porta, M.; Ficara, V.; Manoni, M.; Zuccotti, G.V.; Pinotti, L.; Maier, J.A.; Cazzola, R. Magnesium in Obesity, Metabolic Syndrome, and Type 2 Diabetes. Nutrients 2021, 13, 320. [CrossRef]

6. Rosanoff, A.; Costello, R.B.; Johnson, G.H. Effectively Prescribing Oral Magnesium Therapy for Hypertension: A Categorized Systematic Review of 49 Clinical Trials. Nutrients 2021, 13, 195. [CrossRef] [PubMed]

7. Moher, D.; Liberati, A.; Tetzlaff, J.; Altman, D.G. The PRISMA Group. Preferred reporting items for systematic reviews and meta-analyses: The PRISMA statement. PLoS Med. 2009, 6, e1000097. [CrossRef]

8. Barragán, R.; Llopis, J.; Portolés, O.; Sorlí, J.V.; Coltell, O.; Rivas-García, L.; Asensio, E.M.; Ortega-Azorín, C.; Corella, D.; SánchezGonzález, C. Influence of Demographic and Lifestyle Variables on Plasma Magnesium Concentrations and Their Associations with Cardiovascular Risk Factors in a Mediterranean Population. Nutrients 2020, 12, 1018. [CrossRef]

9. Bersohn, I.; Oelofse, P.J. Correlation of Serum-Magnesium and Serum-Cholesterol Levels in South African Bantu and European Subjects. Lancet 1957, 269, 1020-1021. [CrossRef]

10. Petersen, B.; Christiansen, C.; Hansen, P.F. Treatment of Hypercholesterolaemia and Hypertriglyceridaemia with Magnesium. Acta Med. Scand. 1976, 200, 59-61. [CrossRef]

11. Liu, A.; Xu, P.; Gong, C.; Zhu, Y.; Zhang, H.; Nie, W.; Zhou, X.; Liang, X.; Xu, Y.; Huang, C.; et al. High Serum Concentration of Selenium, but Not Calcium, Cobalt, Copper, Iron, and Magnesium, Increased the Risk of Both Hyperglycemia and Dyslipidemia in Adults: A Health Examination Center Based Cross-Sectional Study. J. Trace Elem. Med. Biol. 2020, 59, 126470. [CrossRef] 
12. Jin, H.; Nicodemus-Johnson, J. Gender and Age Stratified Analyses of Nutrient and Dietary Pattern Associations with Circulating Lipid Levels Identify Novel Gender and Age-Specific Correlations. Nutrients 2018, 10, 1760. [CrossRef] [PubMed]

13. Itoh, K.; Kawasaka, T.; Nakamura, M. The Effects of High Oral Magnesium Supplementation on Blood Pressure, Serum Lipids and Related Variables in Apparently Healthy Japanese Subjects. Br. J. Nutr. 1997, 78, 737-750. [CrossRef]

14. Marken, P.A.; Weart, C.W.; Carson, D.S.; Gums, J.G.; Lopes-Virella, M.F. Effects of Magnesium Oxide on the Lipid Profile of Healthy Volunteers. Atherosclerosis 1989, 77, 37-42. [CrossRef]

15. Randell, E.W.; Mathews, M.; Gadag, V.; Zhang, H.; Sun, G. Relationship between Serum Magnesium Values, Lipids and Anthropometric Risk Factors. Atherosclerosis 2008, 196, 413-419. [CrossRef] [PubMed]

16. Guerrero-Romero, F.; Rodríguez-Morán, M. The Ratio Potassium-to-Magnesium Intake and High Blood Pressure. Eur. J. Clin. Invest. 2019, 49, e13093. [CrossRef]

17. de Valk, H.W.; Bianchi, R.; van Rijn, H.J.; Erkelens, D.W. Acute Exogenous Elevation of Plasma Free Fatty Acids Does Not Influence the Plasma Magnesium Concentration. Clin. Chem. Lab. Med. 1998, 36, 115-117. [CrossRef]

18. Aslanabadi, N.; Habibi Asl, B.; Bakhshalizadeh, B.; Ghaderi, F.; Nemati, M. Hypolipidemic Activity of a Natural Mineral Water Rich in Calcium, Magnesium, and Bicarbonate in Hyperlipidemic Adults. Adv. Pharm. Bull. 2014, 4, $303-307$.

19. Fu, Z.-Y.; Yang, F.L.; Hsu, H.-W.; Lu, Y.-F. Drinking Deep Seawater Decreases Serum Total and Low-Density LipoproteinCholesterol in Hypercholesterolemic Subjects. J. Med. Food 2012, 15, 535-541. [CrossRef] [PubMed]

20. Nerbrand, C.; Agréus, L.; Lenner, R.A.; Nyberg, P.; Svärdsudd, K. The Influence of Calcium and Magnesium in Drinking Water and Diet on Cardiovascular Risk Factors in Individuals Living in Hard and Soft Water Areas with Differences in Cardiovascular Mortality. BMC Public Health 2003, 3, 21. [CrossRef]

21. Luoma, H.; Helminen, S.K.J.; Ranta, H.; Rytömaa, I.; Meurman, J.H. Relationships between the Fluoride and Magnesium Concentrations in Drinking Water and Some Components in Serum Related to Cardiovascular Diseases in Men from Four Rural Districts in Finland. Scand. J. Clin. Lab. Investig. 1973, 32, 217-224. [CrossRef] [PubMed]

22. Balliett, M.; Burke, J.R. Changes in Anthropometric Measurements, Body Composition, Blood Pressure, Lipid Profile, and Testosterone in Patients Participating in a Low-Energy Dietary Intervention. J. Chiropr. Med. 2013, 12, 3-14. [CrossRef] [PubMed]

23. de Los Rios, M.G. Serum Magnesium and Serum Cholesterol Changes in Man. Am. J. Clin. Nutr. 1961, 9, 315-319. [CrossRef]

24. Cocate, P.G.; Natali, A.J.; de Oliveira, A.; Longo, G.Z.; Rita de Cássia, G.A.; Maria do Carmo, G.P.; dos Santos, E.C.; Buthers, J.M.; de Oliveira, L.L.; Hermsdorff, H.H.M. Fruit and Vegetable Intake and Related Nutrients Are Associated with Oxidative Stress Markers in Middle-Aged Men. Nutrition 2014, 30, 660-665. [CrossRef]

25. Ruel, G.; Shi, Z.; Zhen, S.; Zuo, H.; Kröger, E.; Sirois, C.; Lévesque, J.-F.; Taylor, A.W. Association between Nutrition and the Evolution of Multimorbidity: The Importance of Fruits and Vegetables and Whole Grain Products. Clin. Nutr. 2014, 33, 513-520. [CrossRef] [PubMed]

26. Bain, L.K.M.; Myint, P.K.; Jennings, A.; Lentjes, M.A.H.; Luben, R.N.; Khaw, K.-T.; Wareham, N.J.; Welch, A.A. The Relationship between Dietary Magnesium Intake, Stroke and Its Major Risk Factors, Blood Pressure and Cholesterol, in the EPIC-Norfolk Cohort. Int. J. Cardiol. 2015, 196, 108-114. [CrossRef]

27. Samavarchi Tehrani, S.; Khatami, S.H.; Saadat, P.; Sarfi, M.; Ahmadi Ahangar, A.; Daroie, R.; Firouzjahi, A.; Maniati, M. Association of Serum Magnesium Levels with Risk Factors, Severity and Prognosis in Ischemic and Hemorrhagic Stroke Patients. Caspian J. Intern. Med. 2020, 11, 83-91. [PubMed]

28. Kim, D.S.; Burt, A.A.; Ranchalis, J.E.; Jarvik, L.E.; Eintracht, J.F.; Furlong, C.E.; Jarvik, G.P. Effects of Dietary Components on High-Density Lipoprotein Measures in a Cohort of 1,566 Participants. Nutr. Metab. 2014, 11, 44. [CrossRef] [PubMed]

29. Kim, M.-H.; Choi, M.-K. Seven Dietary Minerals (Ca, P, Mg, Fe, Zn, Cu, and Mn) and Their Relationship with Blood Pressure and Blood Lipids in Healthy Adults with Self-Selected Diet. Biol. Trace Elem. Res. 2013, 153, 69-75. [CrossRef]

30. Cao, Y.; Wang, C.; Guan, K.; Xu, Y.; Su, Y.-X.; Chen, Y.-M. Association of Magnesium in Serum and Urine with Carotid IntimaMedia Thickness and Serum Lipids in Middle-Aged and Elderly Chinese: A Community-Based Cross-Sectional Study. Eur. J. Nutr. 2016, 55, 219-226. [CrossRef]

31. López-González, B.; Molina-López, J.; Florea, D.I.; Quintero-Osso, B.; Pérez de la Cruz, A.; Planells del Pozo, E.M. Association between Magnesium-Deficient Status and Anthropometric and Clinical-Nutritional Parameters in Posmenopausal Women. Nutr. Hosp. 2014, 29, 658-664. [PubMed]

32. Yamori, Y.; Sagara, M.; Mizushima, S.; Liu, L.; Ikeda, K.; Nara, Y.; CARDIAC Study Group. An Inverse Association between Magnesium in 24-h Urine and Cardiovascular Risk Factors in Middle-Aged Subjects in 50 CARDIAC Study Populations. Hypertens. Res. 2015, 38, 219-225. [CrossRef] [PubMed]

33. Guerrero-Romero, F.; Rodriguez-Moran, M. Serum Magnesium in the Metabolically-Obese Normal-Weight and Healthy-Obese Subjects. Eur. J. Intern. Med. 2013, 24, 639-643. [CrossRef] [PubMed]

34. Lefebvre, P.; Letois, F.; Sultan, A.; Nocca, D.; Mura, T.; Galtier, F. Nutrient Deficiencies in Patients with Obesity Considering Bariatric Surgery: A Cross-Sectional Study. Surg. Obes. Relat. Dis. 2014, 10, 540-546. [CrossRef] [PubMed]

35. Rodríguez-Moran, M.; Guerrero-Romero, F. Oral Magnesium Supplementation Improves the Metabolic Profile of Metabolically Obese, Normal-Weight Individuals: A Randomized Double-Blind Placebo-Controlled Trial. Arch. Med. Res. 2014, 45, 388-393. [CrossRef]

36. Joris, P.J.; Plat, J.; Bakker, S.J.L.; Mensink, R.P. Effects of Long-Term Magnesium Supplementation on Endothelial Function and Cardiometabolic Risk Markers: A Randomized Controlled Trial in Overweight/Obese Adults. Sci. Rep. 2017, 7, 106. [CrossRef] 
37. Guerrero-Romero, F.; Flores-García, A.; Saldaña-Guerrero, S.; Simental-Mendía, L.E.; Rodríguez-Morán, M. Obesity and Hypomagnesemia. Eur. J. Intern. Med. 2016, 34, 29-33. [CrossRef]

38. Solati, M.; Kazemi, L.; Shahabi Majd, N.; Keshavarz, M.; Pouladian, N.; Soltani, N. Oral Herbal Supplement Containing Magnesium Sulfate Improve Metabolic Control and Insulin Resistance in Non-Diabetic Overweight Patients: A Randomized Double Blind Clinical Trial. Med. J. Islam. Repub. Iran 2019, 33, 2. [CrossRef]

39. Farsinejad-Marj, M.; Azadbakht, L.; Mardanian, F.; Saneei, P.; Esmaillzadeh, A. Clinical and Metabolic Responses to Magnesium Supplementation in Women with Polycystic Ovary Syndrome. Biol. Trace Elem. Res. 2020, 196, 349-358. [CrossRef]

40. Cutler, D.A.; Pride, S.M.; Cheung, A.P. Low Intakes of Dietary Fiber and Magnesium Are Associated with Insulin Resistance and Hyperandrogenism in Polycystic Ovary Syndrome: A Cohort Study. Food Sci. Nutr. 2019, 7, 1426-1437. [CrossRef]

41. Jamilian, M.; Sabzevar, N.K.; Asemi, Z. The Effect of Magnesium and Vitamin E Co-Supplementation on Glycemic Control and Markers of Cardio-Metabolic Risk in Women with Polycystic Ovary Syndrome: A Randomized, Double-Blind, Placebo-Controlled Trial. Horm. Metab. Res. 2019, 51, 100-105. [CrossRef] [PubMed]

42. Jamilian, M.; Maktabi, M.; Asemi, Z. A Trial on the Effects of Magnesium-Zinc-Calcium-Vitamin D Co-Supplementation on Glycemic Control and Markers of Cardio-Metabolic Risk in Women with Polycystic Ovary Syndrome. Arch. Iran. Med. 2017, 20, 640-645. [PubMed]

43. Karandish, M.; Tamimi, M.; Shayesteh, A.A.; Haghighizadeh, M.H.; Jalali, M.T. The Effect of Magnesium Supplementation and Weight Loss on Liver Enzymes in Patients with Nonalcoholic Fatty Liver Disease. J. Res. Med. Sci. 2013, 18, 573-579. [PubMed]

44. Ali, R.; Lee, E.T.; Knehans, A.W.; Zhang, Y.; Yeh, J.; Rhoades, E.R.; Jobe, J.B.; Ali, T.; Johnson, M.R. Dietary Intake among American Indians with Metabolic Syndrome-Comparison to Dietary Recommendations: The Balance Study. Int. J. Health Nutr. 2013, 4, 33-45.

45. Vajdi, M.; Farhangi, M.A.; Nikniaz, L. Diet-Derived Nutrient Patterns and Components of Metabolic Syndrome: A Cross-Sectional Community- Based Study. BMC Endocr. Disord. 2020, 20, 69. [CrossRef]

46. Akbarzade, Z.; Amini, M.R.; Djafari, F.; Yarizadeh, H.; Mohtashaminia, F.; Majdi, M.; Bazshahi, E.; Djafarian, K.; Clark, C.C.T.; Shab-Bidar, S. Association of Nutrient Patterns with Metabolic Syndrome and Its Components in Iranian Adults. Clin. Nutr. Res. 2020, 9, 318-331. [CrossRef]

47. Mottaghian, M.; Salehi, P.; Teymoori, F.; Mirmiran, P.; Hosseini-Esfahani, F.; Azizi, F. Nutrient Patterns and Cardiometabolic Risk Factors among Iranian Adults: Tehran Lipid and Glucose Study. BMC Public Health 2020, 20, 653. [CrossRef]

48. Choi, M.-K.; Bae, Y.-J. Relationship between Dietary Magnesium, Manganese, and Copper and Metabolic Syndrome Risk in Korean Adults: The Korea National Health and Nutrition Examination Survey (2007-2008). Biol. Trace Elem. Res. 2013, 156, 56-66. [CrossRef] [PubMed]

49. Cano-Ibáñez, N.; Gea, A.; Ruiz-Canela, M.; Corella, D.; Salas-Salvadó, J.; Schröder, H.; Navarrete-Muñoz, E.M.; Romaguera, D.; Martínez, J.A.; Barón-López, F.J.; et al. Diet Quality and Nutrient Density in Subjects with Metabolic Syndrome: Influence of Socioeconomic Status and Lifestyle Factors. A Cross-Sectional Assessment in the PREDIMED-Plus Study. Clin. Nutr. 2020, 39, 1161-1173. [CrossRef]

50. Choi, W.-S.; Kim, S.-H.; Chung, J.-H. Relationships of Hair Mineral Concentrations with Insulin Resistance in Metabolic Syndrome. Biol. Trace Elem. Res. 2014, 158, 323-329. [CrossRef] [PubMed]

51. Vanaelst, B.; Huybrechts, I.; Michels, N.; Flórez, M.R.; Aramendía, M.; Balcaen, L.; Resano, M.; Vanhaecke, F.; Bammann, K.; Bel-Serrat, S.; et al. Hair Minerals and Metabolic Health in Belgian Elementary School Girls. Biol. Trace Elem. Res. 2013, 151, 335-343. [CrossRef]

52. Sun, X.; Du, T.; Huo, R.; Yu, X.; Xu, L. Impact of HbA1c Criterion on the Definition of Glycemic Component of the Metabolic Syndrome: The China Health and Nutrition Survey 2009. BMC Public Health 2013, 13, 1045. [CrossRef] [PubMed]

53. Lima de Souza, E.; Silva, M.d.L.; Cruz, T.; Rodrigues, L.E.; Ladeia, A.M.; Bomfim, O.; Olivieri, L.; Melo, J.; Correia, R.; Porto, M.; et al. Magnesium Replacement Does Not Improve Insulin Resistance in Patients with Metabolic Syndrome: A 12-Week Randomized Double-Blind Study. J. Clin. Med. Res. 2014, 6, 456-462. [CrossRef] [PubMed]

54. Rotter, I.; Kosik-Bogacka, D.; Dołegowska, B.; Safranow, K.; Lubkowska, A.; Laszczyńska, M. Relationship between the Concentrations of Heavy Metals and Bioelements in Aging Men with Metabolic Syndrome. Int. J. Environ. Res. Public Health 2015, 12, 3944-3961. [CrossRef]

55. Ghasemi, A.; Zahediasl, S.; Syedmoradi, L.; Azizi, F. Low Serum Magnesium Levels in Elderly Subjects with Metabolic Syndrome. Biol. Trace Elem. Res. 2010, 136, 18-25. [CrossRef]

56. Evangelopoulos, A.A.; Vallianou, N.G.; Panagiotakos, D.B.; Georgiou, A.; Zacharias, G.A.; Alevra, A.N.; Zalokosta, G.J.; Vogiatzakis, E.D.; Avgerinos, P.C. An Inverse Relationship between Cumulating Components of the Metabolic Syndrome and Serum Magnesium Levels. Nutr. Res. 2008, 28, 659-663. [CrossRef]

57. Guerrero-Romero, F.; Rodríguez-Morán, M. Low Serum Magnesium Levels and Metabolic Syndrome. Acta Diabetol. 2002, 39, 209-213. [CrossRef]

58. Yuan, Z.; Liu, C.; Tian, Y.; Zhang, X.; Ye, H.; Jin, L.; Ruan, L.; Sun, Z.; Zhu, Y. Higher Levels of Magnesium and Lower Levels of Calcium in Whole Blood Are Positively Correlated with the Metabolic Syndrome in a Chinese Population: A Case-Control Study. Ann. Nutr. Metab. 2016, 69, 125-134. [CrossRef] 
59. Rotter, I.; Kosik-Bogacka, D.; Dołęgowska, B.; Safranow, K.; Karakiewicz, B.; Laszczyńska, M. Relationship between Serum Magnesium Concentration and Metabolic and Hormonal Disorders in Middle-Aged and Older Men. Magnes. Res. 2015, 28, 99-107. [CrossRef]

60. van Dijk, P.R.; Schutten, J.C.; Jeyarajah, E.J.; Kootstra-Ros, J.E.; Connelly, M.A.; Bakker, S.J.L.; Dullaart, R.P.F. Blood Mg2+ Is More Closely Associated with Hyperglycaemia than with Hypertriacylglycerolaemia: The PREVEND Study. Diabetologia 2019, 62, 1732-1734. [CrossRef]

61. Rusu, M.; Cristea, V.; Frenţiu, T.; Măruţoiu, C.; Rusu, L.D. Magnesium and Selenium in Diabetics with Peripheral Artery Disease of the Lower Limbs. Clujul Med. 2013, 86, 235-239.

62. Spiga, R.; Mannino, G.C.; Mancuso, E.; Averta, C.; Paone, C.; Rubino, M.; Sciacqua, A.; Succurro, E.; Perticone, F.; Andreozzi, F.; et al. Are Circulating $\mathrm{Mg}^{2+}$ Levels Associated with Glucose Tolerance Profiles and Incident Type 2 Diabetes? Nutrients 2019, 11, 2460. [CrossRef]

63. Esmeralda, C.A.C.; David, P.E.; Maldonado, I.C.; Ibrahim, S.N.A.; David, A.S.; Escorza, M.A.Q.; Dealmy, D.G. Deranged Fractional Excretion of Magnesium and Serum Magnesium Levels in Relation to Retrograde Glycaemic Regulation in Patients with Type 2 Diabetes Mellitus. Curr. Diabetes Rev. 2021, 17, 91-100. [CrossRef] [PubMed]

64. Niranjan, G.; Srinivasan, A.R.; Srikanth, K.; Pruthu, G.; Reeta, R.; Ramesh, R.; Anitha, R.; Valli, V.M. Evaluation of Circulating Plasma VEGF-A, ET-1 and Magnesium Levels as the Predictive Markers for Proliferative Diabetic Retinopathy. Indian J. Clin. Biochem. 2019, 34, 352-356. [CrossRef]

65. Hruby, A.; Guasch-Ferré, M.; Bhupathiraju, S.N.; Manson, J.E.; Willett, W.C.; McKeown, N.M.; Hu, F.B. Magnesium Intake, Quality of Carbohydrates, and Risk of Type 2 Diabetes: Results from Three U.s. Cohorts. Diabetes Care 2017, 40, 1695-1702. [CrossRef]

66. Anetor, J.I.; Senjobi, A.; Ajose, O.A.; Agbedana, E.O. Decreased Serum Magnesium and Zinc Levels: Atherogenic Implications in Type-2 Diabetes Mellitus in Nigerians. Nutr. Health 2002, 16, 291-300. [CrossRef]

67. Corica, F.; Corsonello, A.; Ientile, R.; Cucinotta, D. Serum ionized magnesium levels in relation to metabolic syndrome in type 2 diabetic patients. J. Am. Col. Nutr. 2006, 25, 210-215. [CrossRef]

68. Guerrero-Romero, F.; Rodríguez-Morán, M. Hypomagnesemia Is Linked to Low Serum HDL-Cholesterol Irrespective of Serum Glucose Values. J. Diabetes Complicat. 2000, 14, 272-276. [CrossRef]

69. Yu, L.; Zhang, J.; Wang, L.; Li, S.; Zhang, Q.; Xiao, P.; Wang, K.; Zhuang, M.; Jiang, Y. Association between Serum Magnesium and Blood Lipids: Influence of Type 2 Diabetes and Central Obesity. Br. J. Nutr. 2018, 120, 250-258. [CrossRef]

70. Kurstjens, S.; de Baaij, J.H.F.; Bouras, H.; Bindels, R.J.M.; Tack, C.J.J.; Hoenderop, J.G.J. Determinants of Hypomagnesemia in Patients with Type 2 Diabetes Mellitus. Eur. J. Endocrinol. 2017, 176, 11-19. [CrossRef]

71. Rasheed, H.; Elahi, S.; Ajaz, H. Serum Magnesium and Atherogenic Lipid Fractions in Type II Diabetic Patients of Lahore, Pakistan. Biol. Trace Elem. Res. 2012, 148, 165-169. [CrossRef]

72. Srinivasan, A.R.; Niranjan, G.; Kuzhandai Velu, V.; Parmar, P.; Anish, A. Status of Serum Magnesium in Type 2 Diabetes Mellitus with Particular Reference to Serum Triacylglycerol Levels. Diabetes Metab. Syndr. 2012, 6, 187-189. [CrossRef]

73. Pokharel, D.R.; Khadka, D.; Sigdel, M.; Yadav, N.K.; Kafle, R.; Sapkota, R.M.; Jha, S.K. Association of Serum Magnesium Level with Poor Glycemic Control and Renal Functions in Nepalese Patients with Type 2 Diabetes Mellitus. Diabetes Metab. Syndr. 2017, 11, S417-S423. [CrossRef]

74. Hyassat, D.; Al Sitri, E.; Batieha, A.; El-Khateeb, M.; Ajlouni, K. Prevalence of Hypomagnesaemia among Obese Type 2 Diabetic Patients Attending the National Center for Diabetes, Endocrinology and Genetics (NCDEG). Int. J. Endocrinol. Metab. 2014, 12, e17796. [CrossRef]

75. Waanders, F.; Dullaart, R.P.F.; Vos, M.J.; Hendriks, S.H.; van Goor, H.; Bilo, H.J.G.; van Dijk, P.R. Hypomagnesaemia and Its Determinants in a Contemporary Primary Care Cohort of Persons with Type 2 Diabetes. Endocrine 2020, 67, 80-86. [CrossRef]

76. Huang, J.-H.; Lu, Y.-F.; Cheng, F.-C.; Lee, J.N.-Y.; Tsai, L.-C. Correlation of Magnesium Intake with Metabolic Parameters, Depression and Physical Activity in Elderly Type 2 Diabetes Patients: A Cross-Sectional Study. Nutr. J. 2012, 11, 41. [CrossRef]

77. Corsonello, A.; Ientile, R.; Buemi, M.; Cucinotta, D.; Mauro, V.N.; Macaione, S.; Corica, F. Serum Ionized Magnesium Levels in Type 2 Diabetic Patients with Microalbuminuria or Clinical Proteinuria. Am. J. Nephrol. 2000, 20, 187-192. [CrossRef]

78. Shardha, A.K.; Vaswani, A.S.; Faraz, A.; Alam, M.T.; Kumar, P. Frequency and Risk Factors Associated with Hypomagnesaemia in Hypokalemic Type-2 Diabetic Patients. J. Coll. Physicians Surg. Pak. 2014, 24, 830-835.

79. Song, Y.; He, K.; Levitan, E.B.; Manson, J.E.; Liu, S. Effects of Oral Magnesium Supplementation on Glycaemic Control in Type 2 Diabetes: A Meta-Analysis of Randomized Double-Blind Controlled Trials: Review Article. Diabet. Med. 2006, 23, 1050-1056. [CrossRef]

80. Hamedifard, Z.; Farrokhian, A.; Reiner, Ž.; Bahmani, F.; Asemi, Z.; Ghotbi, M.; Taghizadeh, M. The Effects of Combined Magnesium and Zinc Supplementation on Metabolic Status in Patients with Type 2 Diabetes Mellitus and Coronary Heart Disease. Lipids Health Dis. 2020, 19, 112. [CrossRef]

81. Al-Daghri, N.M.; Alkharfy, K.M.; Khan, N.; Alfawaz, H.A.; Al-Ajlan, A.S.; Yakout, S.M.; Alokail, M.S. Vitamin D Supplementation and Serum Levels of Magnesium and Selenium in Type 2 Diabetes Mellitus Patients: Gender Dimorphic Changes. Int. J. Vitam. Nutr. Res. 2014, 84, 27-34. [CrossRef] 
82. Rashvand, S.; Mobasseri, M.; Tarighat-Esfanjani, A. Effects of Choline and Magnesium Concurrent Supplementation on Coagulation and Lipid Profile in Patients with Type 2 Diabetes Mellitus: A Pilot Clinical Trial. Biol. Trace Elem. Res. 2020, 194, $328-335$. [CrossRef]

83. Whitfield, P.; Parry-Strong, A.; Walsh, E.; Weatherall, M.; Krebs, J.D. The Effect of a Cinnamon-, Chromium- and MagnesiumFormulated Honey on Glycaemic Control, Weight Loss and Lipid Parameters in Type 2 Diabetes: An Open-Label Cross-over Randomised Controlled Trial. Eur. J. Nutr. 2016, 55, 1123-1131. [CrossRef]

84. Dehbalaei, M.G.; Ashtary-Larky, D.; Amarpoor Mesrkanlou, H.; Talebi, S.; Asbaghi, O. The Effects of Magnesium and Vitamin E Co-Supplementation on Some Cardiovascular Risk Factors: A Meta-Analysis. Clin. Nutr. Espen 2021, 41, 110-117. [CrossRef]

85. Yokota, K.; Kato, M.; Lister, F.; Ii, H.; Hayakawa, T.; Kikuta, T.; Kageyama, S.; Tajima, N. Clinical Efficacy of Magnesium Supplementation in Patients with Type 2 Diabetes. J. Am. Coll. Nutr. 2004, 23, 506S-509S. [CrossRef] [PubMed]

86. Djurhuus, M.S.; Klitgaard, N.A.; Pedersen, K.K.; Blaabjerg, O.; Altura, B.M.; Altura, B.T.; Henriksen, J.E. Magnesium Reduces Insulin-Stimulated Glucose Uptake and Serum Lipid Concentrations in Type 1 Diabetes. Metabolism 2001, 50, $1409-1417$. [CrossRef]

87. Ham, J.Y.; Shon, Y.H. Natural Magnesium-Enriched Deep-Sea Water Improves Insulin Resistance and the Lipid Profile of Prediabetic Adults: A Randomized, Double-Blinded Crossover Trial. Nutrients 2020, 12, 515. [CrossRef]

88. Cosaro, E.; Bonafini, S.; Montagnana, M.; Danese, E.; Trettene, M.S.; Minuz, P.; Delva, P.; Fava, C. Effects of Magnesium Supplements on Blood Pressure, Endothelial Function and Metabolic Parameters in Healthy Young Men with a Family History of Metabolic Syndrome. Nutr. Metab. Cardiovasc. Dis. 2014, 24, 1213-1220. [CrossRef]

89. Asemi, Z.; Karamali, M.; Jamilian, M.; Foroozanfard, F.; Bahmani, F.; Heidarzadeh, Z.; Benisi-Kohansal, S.; Surkan, P.J.; Esmaillzadeh, A. Magnesium Supplementation Affects Metabolic Status and Pregnancy Outcomes in Gestational Diabetes: A Randomized, Double-Blind, Placebo-Controlled Trial. Am. J. Clin. Nutr. 2015, 102, 222-229. [CrossRef]

90. Navarrete-Cortes, A.; Ble-Castillo, J.L.; Guerrero-Romero, F.; Cordova-Uscanga, R.; Juárez-Rojop, I.E.; Aguilar-Mariscal, H.; Tovilla-Zarate, C.A.; Lopez-Guevara, M.D.R. No Effect of Magnesium Supplementation on Metabolic Control and Insulin Sensitivity in Type 2 Diabetic Patients with Normomagnesemia. Magnes. Res. 2014, 27, 48-56. [CrossRef]

91. Guerrero-Romero, F.; Simental-Mendía, L.E.; Hernández-Ronquillo, G.; Rodriguez-Morán, M. Oral Magnesium Supplementation Improves Glycaemic Status in Subjects with Prediabetes and Hypomagnesaemia: A Double-Blind Placebo-Controlled Randomized Trial. Diabetes Metab. 2015, 41, 202-207. [CrossRef] [PubMed]

92. Solati, M.; Ouspid, E.; Hosseini, S.; Soltani, N.; Keshavarz, M.; Dehghani, M. Oral Magnesium Supplementation in Type II Diabetic Patients. Med. J. Islam. Repub. Iran 2014, 28, 67.

93. de Valk, H.W.; Verkaaik, R.; van Rijn, H.J.; Geerdink, R.A.; Struyvenberg, A. Oral Magnesium Supplementation in InsulinRequiring Type 2 Diabetic Patients. Diabet. Med. 1998, 15, 503-507. [CrossRef]

94. Eriksson, J.; Kohvakka, A. Magnesium and Ascorbic Acid Supplementation in Diabetes Mellitus. Ann. Nutr. Metab. 1995, 39, 217-223. [CrossRef]

95. Talari, H.R.; Zakizade, M.; Soleimani, A.; Bahmani, F.; Ghaderi, A.; Mirhosseini, N.; Eslahi, M.; Babadi, M.; Mansournia, M.A.; Asemi, Z. Effects of Magnesium Supplementation on Carotid Intima-Media Thickness and Metabolic Profiles in Diabetic Haemodialysis Patients: A Randomised, Double-Blind, Placebo-Controlled Trial. Br. J. Nutr. 2019, 121, 809-817. [CrossRef] [PubMed]

96. Afzali, H.; Jafari Kashi, A.H.; Momen-Heravi, M.; Razzaghi, R.; Amirani, E.; Bahmani, F.; Gilasi, H.R.; Asemi, Z. The Effects of Magnesium and Vitamin E Co-Supplementation on Wound Healing and Metabolic Status in Patients with Diabetic Foot Ulcer: A Randomized, Double-Blind, Placebo-Controlled Trial: Supplementation and Diabetic Foot. Wound Repair Regen. 2019, 27, 277-284. [CrossRef]

97. Brandão-Lima, P.N.; Carvalho, G.B.d.; Santos, R.K.F.; Santos, B.D.C.; Dias-Vasconcelos, N.L.; Rocha, V.D.S.; Barbosa, K.B.F.; Pires, L.V. Intakes of Zinc, Potassium, Calcium, and Magnesium of Individuals with Type 2 Diabetes Mellitus and the Relationship with Glycemic Control. Nutrients 2018, 10, 1948. [CrossRef]

98. Karamali, M.; Bahramimoghadam, S.; Sharifzadeh, F.; Asemi, Z. Magnesium-Zinc-Calcium-Vitamin D Co-Supplementation Improves Glycemic Control and Markers of Cardiometabolic Risk in Gestational Diabetes: A Randomized, Double-Blind, Placebo-Controlled Trial. Appl. Physiol. Nutr. Metab. 2018, 43, 565-570. [CrossRef]

99. Sadeghian, M.; Azadbakht, L.; Khalili, N.; Mortazavi, M.; Esmaillzadeh, A. Oral Magnesium Supplementation Improved Lipid Profile but Increased Insulin Resistance in Patients with Diabetic Nephropathy: A Double-Blind Randomized Controlled Clinical Trial. Biol. Trace Elem. Res. 2020, 193, 23-35. [CrossRef]

100. An, G.; Du, Z.; Meng, X.; Guo, T.; Shang, R.; Li, J.; An, F.; Li, W.; Zhang, C. Association between Low Serum Magnesium Level and Major Adverse Cardiac Events in Patients Treated with Drug-Eluting Stents for Acute Myocardial Infarction. PLoS ONE 2014, 9, e98971. [CrossRef]

101. Qazmooz, H.A.; Smesam, H.N.; Mousa, R.F.; Al-Hakeim, H.K.; Maes, M. Trace Element, Immune and Opioid Biomarkers of Unstable Angina, Increased Atherogenicity and Insulin Resistance: Results of Machine Learning. J. Trace Elem. Med. Biol. 2021, 64, 126703. [CrossRef]

102. Brown, D. Magnesium-Lipid Relations in Health and in Patients with Myocardial Infarction. Lancet 1958, 272, 933-935. [CrossRef]

103. Mahalle, N.; Kulkarni, M.V.; Naik, S.S. Is Hypomagnesaemia a Coronary Risk Factor among Indians with Coronary Artery Disease? J. Cardiovasc. Dis. Res. 2012, 3, 280-286. [CrossRef] 
104. Liao, F.; Folsom, A.R.; Brancati, F.L. Is Low Magnesium Concentration a Risk Factor for Coronary Heart Disease? The Atherosclerosis Risk in Communities (ARIC) Study. Am. Heart J. 1998, 136, 480-490. [CrossRef]

105. Farshidi, H.; Sobhani, A.R.; Eslami, M.; Azarkish, F.; Eftekhar, E.; Keshavarz, M.; Soltani, N. Magnesium Sulfate Administration in Moderate Coronary Artery Disease Patients Improves Atherosclerotic Risk Factors: A Double-Blind Clinical Trial Study. J. Cardiovasc. Pharmacol. 2020, 76, 321-328. [CrossRef] [PubMed]

106. Petersen, B.; Schroll, M.; Christiansen, C.; Transbol, I. Serum and Erythrocyte Magnesium in Normal Elderly Danish People. Relationship to Blood Pressure and Serum Lipids. Acta Med. Scand. 1977, 201, 31-34. [CrossRef] [PubMed]

107. Posadas-Sánchez, R.; Posadas-Romero, C.; Cardoso-Saldaña, G.; Vargas-Alarcón, G.; Villarreal-Molina, M.T.; Pérez-Hernández, N.; Rodríguez-Pérez, J.M.; Medina-Urrutia, A.; Jorge-Galarza, E.; Juárez-Rojas, J.G.; et al. Serum Magnesium Is Inversely Associated with Coronary Artery Calcification in the Genetics of Atherosclerotic Disease (GEA) Study. Nutr. J. 2015, 15, 22. [CrossRef] [PubMed]

108. Lee, S.Y.; Hyun, Y.Y.; Lee, K.B.; Kim, H. Low Serum Magnesium Is Associated with Coronary Artery Calcification in a Korean Population at Low Risk for Cardiovascular Disease. Nutr. Metab. Cardiovasc. Dis. 2015, 25, 1056-1061. [CrossRef]

109. Zemel, P.C.; Zemel, M.B.; Urberg, M.; Douglas, F.L.; Geiser, R.; Sowers, J.R. Metabolic and Hemodynamic Effects of Magnesium Supplementation in Patients with Essential Hypertension. Am. J. Clin. Nutr. 1990, 51, 665-669. [CrossRef]

110. Motoyama, T.; Sano, H.; Fukuzaki, H. Oral Magnesium Supplementation in Patients with Essential Hypertension. Hypertension 1989, 13, 227-232. [CrossRef]

111. Guerrero-Romero, F.; Rodríguez-Morán, M. The Effect of Lowering Blood Pressure by Magnesium Supplementation in Diabetic Hypertensive Adults with Low Serum Magnesium Levels: A Randomized, Double-Blind, Placebo-Controlled Clinical Trial. J. Hum. Hypertens. 2009, 23, 245-251. [CrossRef]

112. Esfandiari, S.; Bahadoran, Z.; Mirmiran, P.; Tohidi, M.; Azizi, F. Adherence to the Dietary Approaches to Stop Hypertension Trial (DASH) Diet Is Inversely Associated with Incidence of Insulin Resistance in Adults: The Tehran Lipid and Glucose Study. J. Clin. Biochem. Nutr. 2017, 61, 123-129. [CrossRef] [PubMed]

113. Cunha, A.R.; D’El-Rei, J.; Medeiros, F.; Umbelino, B.; Oigman, W.; Touyz, R.M.; Neves, M.F. Oral Magnesium Supplementation Improves Endothelial Function and Attenuates Subclinical Atherosclerosis in Thiazide-Treated Hypertensive Women. J. Hypertens. 2017, 35, 89-97. [CrossRef]

114. Karppanen, H.; Tanskanen, A.; Tuomilehto, J.; Puska, P.; Vuori, J.; Jäntti, V.; Seppänen, M.-L. Safety and Effects of Potassium- and Magnesium-Containing Low Sodium Salt Mixtures. J. Cardiovasc. Pharmacol. 1984, 6, S236. [CrossRef]

115. Delva, P.; Pastori, C.; Degan, M.; Montesi, G.; Lechi, A. Intralymphocyte Free Magnesium and Plasma Triglycerides. Life Sci. 1998, 62, 2231-2240. [CrossRef]

116. Toprak, O.; Sarı, Y.; Koç, A.; Sarı, E.; Kırık, A. The Impact of Hypomagnesemia on Erectile Dysfunction in Elderly, Non-Diabetic, Stage 3 and 4 Chronic Kidney Disease Patients: A Prospective Cross-Sectional Study. Clin. Interv. Aging 2017, 12, 437-444. [CrossRef]

117. Khatami, M.R.; Mirchi, E.; Khazaeipour, Z.; Abdollahi, A.; Jahanmardi, A. Association between Serum Magnesium and Risk Factors of Cardiovascular Disease in Hemodialysis Patients. Iran. J. Kidney Dis. 2013, 7, 47-52.

118. Dey, R.; Rajappa, M.; Parameswaran, S.; Revathy, G. Hypomagnesemia and Atherogenic Dyslipidemia in Chronic Kidney Disease: Surrogate Markers for Increased Cardiovascular Risk. Clin. Exp. Nephrol. 2015, 19, 1054-1061. [CrossRef]

119. Cambray, S.; Ibarz, M.; Bermudez-Lopez, M.; Marti-Antonio, M.; Bozic, M.; Fernandez, E.; Valdivielso, J.M. Magnesium Levels Modify the Effect of Lipid Parameters on Carotid Intima Media Thickness. Nutrients 2020, 12, 2631. [CrossRef]

120. Gupta, B.K.; Glicklich, D.; Tellis, V.A. Magnesium Repletion Therapy Improves Lipid Metabolism in Hypomagnesemic Renal Transplant Recipients: A Pilot Study. Transplantation 1999, 67, 1485-1487. [CrossRef] [PubMed]

121. Liu, F.; Zhang, X.; Qi, H.; Wang, J.; Wang, M.; Zhang, Y.; Yan, H.; Zhuang, S. Correlation of Serum Magnesium with Cardiovascular Risk Factors in Maintenance Hemodialysis Patients-a Cross-Sectional Study. Magnes. Res. 2013, 26, 100-108. [CrossRef] [PubMed]

122. Han, Z.; Zhou, L.; Liu, R.; Feng, L. The Effect of Hemodialysis on Serum Magnesium Concentration in Hemodialysis Patients. Ann. Palliat. Med. 2020, 9, 1134-1143. [CrossRef] [PubMed]

123. Mortazavi, M.; Moeinzadeh, F.; Saadatnia, M.; Shahidi, S.; McGee, J.C.; Minagar, A. Effect of Magnesium Supplementation on Carotid Intima-Media Thickness and Flow-Mediated Dilatation among Hemodialysis Patients: A Double-Blind, Randomized, Placebo-Controlled Trial. Eur. Neurol. 2013, 69, 309-316. [CrossRef]

124. Shimohata, H.; Yamashita, M.; Ohgi, K.; Tsujimoto, R.; Maruyama, H.; Takayasu, M.; Hirayama, K.; Kobayashi, M. The Relationship between Serum Magnesium Levels and Mortality in Non-Diabetic Hemodialysis Patients: A 10-Year Follow-up Study. Hemodial. Int. 2019, 23, 369-374. [CrossRef]

125. Robles, N.R.; Escola, J.M.; Albarran, L.; Espada, R. Correlation of Serum Magnesium and Serum Lipid Levels in Hemodialysis Patients. Nephron 1998, 78, 118-119. [CrossRef] [PubMed]

126. Tamura, T.; Unagami, K.; Okazaki, M.; Komatsu, M.; Nitta, K. Serum Magnesium Levels and Mortality in Japanese Maintenance Hemodialysis Patients. Blood Purif. 2019, 47 (Suppl. 2), 88-94. [CrossRef]

127. Ansari, M.R.; Maheshwari, N.; Shaikh, M.A.; Laghari, M.S.; Lal, K.; Ahmed, K. Correlation of Serum Magnesium with Dyslipidemia in Patients on Maintenance Hemodialysis. Saudi J. Kidney Dis. Transpl. 2012, 23, 21-25.

128. Nasri, H.; Baradaran, A. Correlation of Serum Magnesium with Dyslipidemia in Maintenance Hemodialysis Patients. Acta Med. (Hradec Kral.) 2004, 47, 263-265. [CrossRef] 
129. Ikee, R.; Toyoyama, T.; Endo, T.; Tsunoda, M.; Hashimoto, N. Impact of Sevelamer Hydrochloride on Serum Magnesium Concentrations in Hemodialysis Patients. Magnes. Res. 2016, 29, 184-190. [CrossRef]

130. Mitwalli, A.H. Why Are Serum Magnesium Levels Lower in Saudi Dialysis Patients? J. Taibah Univ. Med. Sci. 2017, 12, 41-46. [CrossRef]

131. Cai, K.; Luo, Q.; Dai, Z.; Zhu, B.; Fei, J.; Xue, C.; Wu, D. Hypomagnesemia Is Associated with Increased Mortality among Peritoneal Dialysis Patients. PLoS ONE 2016, 11, e0152488. [CrossRef]

132. Barbagallo, M.; Veronese, N.; Dominguez, L.J. Magnesium in Aging, Health and Diseases. Nutrients 2021, 13, 463. [CrossRef]

133. Barbagallo, M.; Di Bella, G.; Brucato, V.; D’Angelo, D.; Damiani, P.; Monteverde, A.; Belvedere, M.; Dominguez, L.J. Serum Ionized Magnesium in Diabetic Older Persons. Metabolism 2014, 63, 502-509. [CrossRef]

134. Veronese, N.; Demurtas, J.; Pesolillo, G.; Celotto, S.; Barnini, T.; Calusi, G.; Caruso, M.G.; Notarnicola, M.; Reddavide, R.; Stubbs, B.; et al. Magnesium and Health Outcomes: An Umbrella Review of Systematic Reviews and Meta-Analyses of Observational and Intervention Studies. Eur. J. Nutr. 2020, 59, 263-272. [CrossRef] [PubMed]

135. Fiorentini, D.; Cappadone, C.; Farruggia, G.; Prata, C. Magnesium: Biochemistry, Nutrition, Detection, and Social Impact of Diseases Linked to Its Deficiency. Nutrients 2021, 13, 1136. [CrossRef] [PubMed]

136. Găman, M.-A.; Cozma, M.-A.; Dobrică, E.-C.; Bacalbașa, N.; Bratu, O.G.; Diaconu, C.C. Dyslipidemia: A Trigger for Coronary Heart Disease in Romanian Patients with Diabetes. Metabolites 2020, 10, 195. [CrossRef] [PubMed]

137. Frank, J.; Kisters, K.; Stirban, O.A.; Obeid, R.; Lorkowski, S.; Wallert, M.; Egert, S.; Podszun, M.C.; Eckert, G.P.; Pettersen, J.A.; et al. The Role of Biofactors in the Prevention and Treatment of Age-Related Diseases. Biofactors 2021. [CrossRef] [PubMed]

138. Stepura, O.B.; Martynow, A.I. Magnesium Orotate in Severe Congestive Heart Failure (MACH). Int. J. Cardiol. 2009, 131, $293-295$. [CrossRef] [PubMed]

139. Kisters, K.; Gremmler, B.; Gröber, U. Magnesium deficiency in hypertensive heart disease. J. Hypertens. 2015, 33, e273. [CrossRef] 